\title{
Kutlama ve Armağanlarca Kuşatılan Annelik: Diş Buğdayı, Baby Shower ve Annelik Eksenindeki Diğer Ritüeller
}

\author{
Motherhood Surrounded by Gifts and Celebration: Tooth Wheat, Baby Shower \\ and Other Rituals on the Axis of Motherhood
}

\section{Berre ALTAŞ*}

Öz: Tüketim ve annelik özelinde düşünüldüğünde, hâkim tüketim kültürünün annelerin neyi önemsemeleri, nasıl davranmaları, niçin ilgili ürün, hizmet ya da uygulamaları tercih etmeleri gerektiğine dair özel imgeler oluşturduğunu belirtmek gerekmektedir. Bu bağlamda güncel annelik gerekleri de şekillenmekte ve yaşanan gelişmelerin etkisiyle bebekler adeta metalaştırılmaktadır. Yaşananlar neticesinde bebek geçmişteki örneklerden farklı bir toplumsal kategoriye sahip olmuş ve biyolojik doğumla sosyal doğum iç içe geçmiştir. Günümüzde tüm bu içerikleri annelik ve çocuk ekseninde gerçekleşen kutlama ve armağanlaşma ritüellerinden de okumak mümkündür. Kutlama ve armağanlaşma pratiklerinin artması, ticarileşmesi ve toplumdaki çoğu kesimce kabullenilip uygulanması geç kapitalizminin kültürel mantı̆̆ına denk düşmekte ve konuyu incelemeye değer kılmaktadır. Bu süreç sonucunda anneler, babalar ve sevgililer günü gibi tüketim kültürü çerçevesinde kapitalizme hizmet eden günlere ve mevcut armağanlaşma ritüellerine ilave olarak annelik ve çocuk çerçevesinde de çeşitli günler, kutlama ritüelleri ve armağanlaşma pratikleri eklenmiştir. Çalışması kapsamında gerçekleşen kutlama ve armağanlaşma ritüellerinin içerimlerini çözümleyebilmek için 50 anne ile yarı yapılandırılmış bir mülakat formu ve ses kayıt cihazı aracılığıyla derinlemesine görüşme gerçekleştirilmiştir. Müdahale edilmeden deşifre edilen görüşmeler neticesinde annelerin gerçekleştirdikleri ritüeller, bu ritüelleri gerçekleştirme nedenleri, ritüellere bakışları irdelenmiştir.

\section{Anahtar sözcükler: Annelik, Tüketim, Kutlama, Armağanlaşma}

\begin{abstract}
In terms of consumption and motherhood, it should be noted that the dominant consumer culture creates special images about what mothers should care about, how they should behave, why they should choose particular products, services or applications. In this context, current maternity requirements are shaped and babies are literally commodified by these developments. In consequence, the baby has a different social category than previously, and the biological birth and social birth were intertwined. Today, it is possible to read all these contents from the celebration and gifting rituals that take place on the axis of motherhood and child. The increase in the practices of celebration and gifting, its commercialization and the acceptance and application of most of society in the society correspond to the cultural logic of late capitalism, make this issue worthy of study. As a result of this process, various days, celebration rituals and gifting practices have been added to motherhood and children, in addition to the days that serve capitalism in the context of consumption culture such as: mothers, fathers and lovers' day, and the present gifting rituals. In order to be able to analyze the rituals of celebration and gifting rituals, a semi-structured interview form with 50 mothers and in-depth interviews were conducted through a voice recorder. The rituals performed by the mothers as a result of the interviewed interviews were examined and the reasons for performing these rituals and their view of the rituals are examined.
\end{abstract}

Keywords: Motherhood, Consumption, Celebration, Gift Exchange

Öğr. Gör. Dr., Akdeniz Üniversitesi, Sosyal Bilimler Meslek Yüksekokulu, Büro Yönetimi ve Yönetici Asistanlığı Programı, Antalya. berrealtas@akdeniz.edu.tr 
“...gerçek, giderek artan sayıda insanın -ne kadar az paraları olsa da- şeyleri kim olduklarını göstermek için kullanma oyununa katıldığıdır"

“... the truth is that an increasing number of people - although they have little money-are involved in a kind of game that using the things to show who they are".

(Hall 1995)

\section{Giriş}

Günümüzde gittikçe artan ürün ve hizmet çeşitliliğinin bireyi sahip olduğu her rol için çeşitli tüketim alışkanlıklarını benimsemeye yönlendirdiğini belirtmek mümkündür. Çeliktaban’a (2014) göre günümüzde çocuk sahibi olmak kişiyi ister istemez bu çark içine sokmakta ve annelerin "doğumdaki haklarından çok hangi puseti alacağına, nasıl bir baby shower partisi organize edeceğine, hastane kapısının süslerinin nasıl olması gerektiği” gibi düşüncelere odaklanmalarina neden olmaktadir.

Çalışma konusu bağlamında düşünüldüğünde annelik kapsamında gerçekleştirilen kutlama ve armağanlaşma ritüellerini de popüler kültür tarafından benimsenmiş bir tüketim pratiği olarak ele almak mümkündür. Dolayısıyla küreselleşmenin de etkisi ile dünya genelinde ünlü sanatçıların gerçekleştirdiği baby shower organizasyonları, hastane odası süslemeleri, ilk yaş kutlamaları gibi annelik ve çocuk eksenindeki diğer kutlama ve armağanlaşma pratikleri kitle iletişim araçları ile diğer annelerle tanıştırılır. Bu aşamadan sonra çeşitli konulardaki görece aşırılıklar ya da süregelen geleneksel pratiklerle alakası olmayan uygulamalar da normalleşmiş, yaygınlaşmış ve benimsenmiş olur. Bu normalleşme, yaygınlaşma ve aşırılıkların gözlemleneceği en geçerli alanlardan biri Mauss’a (2002) göre toplumsal ilişki kurmanın bir boyutu olarak karşılanan armağanlaşma pratikleridir. Böylece armağanlaşma pratikleri üzerinden toplumsal ilişkilerin mevcut durumunu analiz etmek de mümkün olmamaktadır. Byström'a (2015) göre anlam yüklenmiş sembollerle yapılandırılan sembolik eylemler ritüel olarak karşılanmaktadır. Ona göre ritüeller insan tutumlarını etkileme, dönüştürme gücüne sahiptir. $\mathrm{Bu}$ bağlamda annelik ve çocuk ekseninde gerçekleşen ritüellerin sembolik yapısının armağanlar olarak karşılanabileceği düşünülebilir. Günümüzde gerçekleştirilen kutlama ritüellerinin beraberinde getirdiği armağanlaşma pratikleri de araştırma kapsamında irdelenmiş, geleneksel ritüellerde misafirlere sunulan ikramlıklardan ibaret olan "kutlama armağanı" algısının günümüzde geçirdiği dönüşüm ayrıca incelemeye tabi tutulmuştur. Clarke (2007b) ise günümüzde artan armağanlaşma pratiklerini "çağdaşs tüketici kültürünün ve anneliğin toplumsal sürecinin ayrlmaz bir parçası" olarak belirtmekte ve bu pratiklerin tüketimle olan ilişkisini vurgulamaktadır. Bu ilişki ise annelik için süregelenlerden farklı bir baskı yapılandırmaktadır. Beck ve Gernsheim (2012) Kaufmann'ın (1982) söyleminden hareketle günümüzde ailenin ama özellikle annenin tarihte eşi benzeri görülmemiş bir çocuk yetiştirme baskısı altında olduğunu vurgularlar. Onlara göre 20. yüzyılın ebeveynlerine, annelerine "yetiştirme çılgıılı̆̆ı" (1982, 229) denebilecek bir virüs bulaşmıştır. Yetiştirme çılgınlığının temel gerekliliği ise gittikçe artan bir oranda sorumluluk ilkesi çerçevesinde hatasız, kusursuz bir ebeveynlik ama daha çok annelik gerçekleştirme pratiğidir. Bu bağlamda annelik zorlaşmış, karmaşıklaşmış, anne olma yaşı artmış ve tek çocuklu ailelerin sayısı gittikçe çoğalmaya başlamıştır. Bu duruma anneler açısından yaklaşan Gündüz (2017) "süper anne sendromu” (Aynı zamanda modern anne ve zorlanmış anne sendromu da denmektedir.) kavramından hareketle günümüz annesiyle empati kurmamızı sağlar. Ona göre sahip olduğu her rolü kusursuz gerçekleştirmeye çabalayan annelerin yaşadığı durumun belirleyicileri Besser vd. (2010) tarafından artan toplumsal rol, beklenti ve sorumluluklar, modern şehir hayatının güçlükleri ve annelik olgusunun sosyal tanımı olarak değerlendirilir. Daha çok çalışan annelerin yaşama ihtimalinin yüksek olduğuna değinilen bu 
sendrom hem anneliğin kusursuz bir şekilde gerçekleştirilmesine hem de annenin diğer rollerinin gerektirdiklerini de eksiksiz olarak yerine getirmesine odaklanmaktadır. Bu bağlamda vurgulanması gereken, kadın üzerinden biçimlendirilmeye çalışılan idealin adeta bir "süper kahramanı" andırdığıdır. Hâkim koşullarca annelik ekseninde idealleştirilen eylemlerin, ürünlerin, hizmetlerin ve anneyi "kusursuzluğa" yaklaştıracağını vadeden diğer unsurların amaç haline gelen bir içeriği bulunmaktadır. Bu unsurların büyük bir kısmına ulaşmanın yolu ise tüketimle mümkün görünmektedir.

\section{Tüketici Olarak Anne ve Anneliğin Sınayıcısı Olarak Tüketim}

Anneden çocuk gibi kutsal, eşsiz ve yüce oluşumun mutluluğunu garanti etme konusunda üzerine düşen sorumlulukları yerine getirmesi beklenir. İçinde bulunduğumuz koşullarda bu beklentiyi yerine getirme aracının tüketim ürün ve hizmetlerinden geçtiği düşüncesi yaygın bir kabuldür. Özellikle kapitalizm ile değişen yaklaşımlar çalışan ya da çalışmayan annelere tüketim aracılığı ile anneliklerini sınama ve kanıtlama imkânı sunmuştur. Annelerin anneliklerini sınadıkları bir araç haline gelen tüketim Zengingönül'e (2012) göre günümüzde annelik ve çocuk yetiştirme ile iç içe geçmiştir. Gram ve Pedersen (2014) günümüzde tüketim varlıklarının ve bu varlıklar üzerinden anneliğin tanımlanma süreçlerinin birbiri ile bağlantılı hale gelmiş olduğunu belirtmektedir. Onlara göre tüketim artık annenin temel eylemlerinden biri olma konusunda önemli bir araç olarak görülmektedir. Dolayısıyla annelik olgusunun ve iyi anne idealinin gereklilikleri, son yıllara kadar hiç olmadığı kadar değişmiş ve âdeta tüketim aktörlerince kuşatılmış durumdadır.

Kapitalist sürecin hızını artırması ile birlikte özel alana ait olan kadın 1960'lı yıllardan itibaren kamusal alanda ve çalışma hayatında aktif olarak yer almaya başlamıştır. Ekonomik koşulların gittikçe zorlaşması sadece babanın çalışmasının yetmediği ve annenin de desteğinin şart olduğu bir dönemi beraberinde getirmiştir. "Bu nedenle tüketim kalıplarl, yalnızca erkeklere özgü değil, kadınları da içine alan bir yöneliş sergilemiştir” (Bocock 2009, 32-34). Kadının tüm rolleri ile birlikte aktif olarak yer aldığı tüketim piyasasının aktörleri bir süre sonra bu çok yönlü tüketici kesimi fark etmiş ve onun algılarını şekillendirme çabasına girmiştir.

Kadın olarak anne, öğretmen, çalışan, ev hanımı ve diğer rollere sahip kişilerin tüketim mal ve hizmetlerine olan algı ve ihtiyaçları farklılık gösterse de, Furedi (2013) zeki girişimcilerin, çocuklarına üstünlük sağlamak isteyen çaresiz ebeveynler üzerinden kazanılacak paranın mevcut olduğunu fark ettiklerini belirtir. Dolayısıyla ebeveynler ama özellikle çocuk bakımından birincil sorumlu olan annelerin günümüzde birçok sektörün hedef tüketicisi olduğunu söylemek mümkündür. Kadınların annelikleri üzerinden kazanılabilecek ekonomik gelirin alternatifli ve tatmin edici hali pazar öncülerini harekete geçirir. Çünkü "Her şey bir nedenle üretilir; her şey, anında tanınan ve aşikâr olan bir sosyal amacın parçasıdır ve bu üretim ediminin üretimin kendisi için yapıldı̆̆ı kişiden ayrılması" (Godbout 2003, 223) mümkün değildir. $\mathrm{Bu}$ doğrultuda öncelikle annelerin algılarını yönlendirmek ve daha çok tüketmelerini sağlamak piyasanın temel amaçlardan biri olarak şekillenmeye başlar. Ailelerin çocukları için her daim en iyiyi istiyor olması ve bu uğurda ekonomik koşulları çok fazla önemsememeleri onları birçok sektör için kolay hedef haline getirmekte, yeni bir aile türü olarak “çocuk merkezli aile”yi (Beck \& Gernsheim 2012, 265) yaygınlaştırmaktadır. Çocuk merkezli aileler bu konudaki hâkim sektörün hedef kitlesidir. Bu noktada çocuk sahibi olmanın maddi manevi aile kaynaklarının çocuğa adanmasını gerekli kılan içeriğine de çocuk bakımının temelindeki adanmışlık eylemine de değinilebilir. Bu bağlamda Giddens (2000) da benzer duruma dikkat çekerek çocuğun hanedeki rolünün merkezîleşen konumuna vurgu yapar. Konuya Balta (2005) da benzer bir şekilde yaklaşarak "sonsuz çocukluk" durumundan bahseder ve dünyanın merkezine konulan bu 
durumun hem çocukluğu mutlaklaştırdığını hem de sonsuz bir tüketimle şekillenen aileler üzerinde daha çok egemen olduğunu belirtir. Çocuk merkezli yaşam ve tüketim ekseninde şekillenen yeni aile yapısı Aries'in de (1996) dikkatini çekmiş ve artık çocukların evde en büyük, en konforlu odaya yerleştiğini ebeveynlerin ise çocukların her türlü kararına saygı duyan, daima sabırlı ve onların isteklerini yerine getiren "kolaylaştırıcı"lar haline geldiğini belirtmiştir. Ayrıca kendisi piyasa-tüketim kültürü ve yeni ebeveynlik arasındaki ilişkiyi ima ederek günümüz ideal ebeveynlik anlayışının çocukların daimî memnuniyetine ve para dâhil olmak üzere her türlü isteklerinin yerine getirilmesine dayandığını belirtir. Dünyaya gelen bebeğin her konuda öncelikli olan konumu "ona her şeyi sunmalıyım" düşüncesi ile hareket etmeye başlayan annenin çocuğu için en iyisi olduğunu düşündüğü ya da bu konuda ikna olduğu ürün ve hizmetleri almaya başlamasına neden olur. Furedi'ye göre bebek ve ebeveyn determinizmi argümanları üzerinden bir endüstri inşa edilmekte ve girişimciler ebeveynlere çocuklarının ilk yıllarında maksimum oranda uyarılmalarını sağlayacak her türlü aygıtı sunarak onları sömürmektedirler $(2013,111)$. Server ise çocuğun “piyasalaştırllması"nın, yalnızca çocuk sahibi olma teknolojilerinden ibaret olmadığını ve bugün gerçekten çok kârlı bir tüketim piyasasının tuğlasına dönüştüğünü belirtmektedir $(2014,80)$. Clarke’a (2014) göre ise günümüzde bir kadının iyi bir anne olması için hangi özellikleri taşıması gerektiği annelerin sorumluluklarını daha da zenginleştirirken, çocukların bir tüketim projesi haline gelmelerine neden olmaktadır. Dolayısıyla çocuk daha çok tüketmek için geçerli bir sebeptir ve nitekim Maier'in, çocuğu "kapitalizmin objektif müttefiki" $(2015,53)$ olarak tanımlaması da bu noktada son derece anlaşılırdır. Kadının hamileliği ile birlikte iyi anne olarak tanımlanmaya başlanmasının bir diğer yolu da çeşitli ürün ve hizmetleri tüketmesi ya da tüketmemesi olarak karşımıza çıkmaktadır. Hamilelik ile başlayan doğrudan bebek için ve dolaylı yoldan ise ebeveynler için geliştirilmiş bu sektör şüphesizdir ki anneliğin idealize edilmesinde rol oynamaktadır. Annenin hissetmesi istenilen "yanlış yapmamalıyım" düşüncesi onları hep görece doğruyu ve en iyiyi aramaya, bu amaç ekseninde de sürekli tüketime iter. Davies ve arkadaşları (2010) yanlış kararların tüketilmesi, tüketicilerin istenen ve idealize ettikleri kimliklerini oluşturmalarını önemli derecede zayıflattığını belirtmekte, Thomsen ve Sorensen (2006) ise bu durumu anneler üzerinden örneklendirerek; yeni bir annenin ilk çocuğu için aldığ 1 nispeten diğerlerinden daha ucuz olan bebek arabası nedeniyle kendisini nasıl yanlış yorumlandığını anlatmaktadırlar. Bu koşullarda annenin tüketim tercihlerine göre hissedeceği suçluluk, tatmin, kendine güven yaşamıyla iç içe geçer. Çocuğun davranışlarından, başarı ve başarısızlıklarından öncelikli olarak aileyi fakat çoğunlukla anneyi sorumlu tutan yaklaşım ve argümanların annelerde bir tedirginliğe, baskıya sebep olduğu aşikardır. Çünkü yetişkinler annelik rolleri üzerinden diğerlerinin kendileri hakkındaki görüş, eleştiri, beğeni ve diğer düşüncelerini önemserler. "Beslenmeye, giyimkuşama, kozmetiğe değin tüm tercih uzamlarl, sermayenin hacmi ve yapısına göre belirlenen toplumsal uzamla aynı temel yapıya göre düzenlenir" $(2015,306)$ diyen Bourdieu'dan hareketle aslında annelerin çocuklarını yetiştirirken aynı zamanda kendilerini toplumsal uzam çercevesinde yeniden inşa ettiklerini belirtmek mümkündür. İşte bu süreç annenin tüketim alışkanlıklarında da bir yeniden yapılanmayı beraberinde getirmektedir. Bu "annesel dünyada" dolaylı yoldan çocuğun da birincil beğeni kriterleri oluşmaya başlar. Bu süreçte beğeni üzerindeki kültürel yapıların temelleri çocuk içinde oluşmaya başlar. Bourdieu’ya göre çocuğun içine doğduğu dünya, çocukluk evreni, her şeyden önce annesel dünyadır. Bu dünyada haz vermenin, hazzın ve hazza dair seçiciliğin kriterleri oluşur $(2015,125)$. Günümüzde haz kaynağı olan ihtiyaçların geç modernitede annelik sorumlulukları, anne-çocuk ilişkisi ve iyi anneliğin güçlü ve hâkim yorumları üzerinden kavramsallaştırılması 1999 yılında Duncan ve Edwards tarafından çalışılmıştır. Bu çalışmada çocuğun çok yönlü ihtiyaçları ile annelik sorumlulukları 
arasındaki çağrışımdan söz edilmiştir. Miller'e göre ise çocuk ihtiyaçları ve annelik sorumluluklarına ilişkin katı yorumlar birçok batı toplumunda hâlâ geçerliliği sürdürmektedir. Bu durumun bir sonucu olarak birçok kadın sonradan inkâr etmelerine rağmen anne oldukları ilk dönemde otoriter bilginin, tıbbileşmenin hiyerarşik biçimlerini kabul eder ve büyük ölçüde onlara bağlanmış olur (2010: 254). Dolayısıyla annelerin kabul ettiği bu bilgi kaynakları onun anne olarak tüketim kalıplarını da değiştirebilir. Bu doğrultuda anne olmadan önce diğer annelerin yaklaşımlarına ya da gerçekleştirdikleri kutlama ve armağanlaşma ritüellerine eleştirel bir tutum geliştiren kadın anne olduktan sonra çocuk eksenindeki birçok davranışı sahiplenebilir.

\section{Armağan Üzerine}

Yadigâr, hibe ödül, rüşvet, ihsan, lütuf, ülüş, hörmet, bahşiş, eşantiyon, inayet hediye ya da en s1k kullanılan ismi ile "armağan" insanlığın en eski geleneklerinden biri olarak tarihin her evresinde toplumsal yaşamda var olmuş bir kültür kalıbıdır. Türk Dil Kurumu Sözlügünde "bir kimseyi sevindirmek, mutlu etmek için verilen şey" olarak tanımlanan armağan, kimi zaman kutsallık çerçevesinde tanrılara sunulmuş, kimi zaman karşılıklılık esası çerçevesinde bir beklentinin örtük mesajı olmuş, kimi zaman da kişiye verilen değerin somut bir göstergesi olarak kabul edilmiştir. Godbout'a göre armağan "bireyler arası sosyal bağları inşa etmek, yeniden üretmek amacıyla verilen ve karşılıklıllk garantisi olmayan her türlü mal ve hizmet olarak" $(2003,18)$ tanımlanmaktadır. Çalışmada ise armağan ve hediye aynı anlamlarda kullanılmış olmakla birlikte Demez'in değindiği gibi “armağan daha çok bir ekonomik sisteme ve mübadeleye işaret ederken; hediye kavramı daha çok kişisel alanda gerçekleşen ve kişiler arası etkileşimi ifade eden dolayıslyla maddi değerden çok sembolik değeri olan ve duygusal yatırım ve beklentiler içeren süreçlere denk gelmektedir" (2011, 91).

İçinde bulunduğumuz tüketim toplumunda armağanlaşma da kendi içinde bir sektör oluşturmuştur. Kapitalizm ruhuna uygun bir şekilde ürün ya da hizmetlere yüklenen çeşitli anlamlarla bu tüketimin artırılması, çeşitlenmesi amaç edinilmiştir. Dolayısıyla "tüketim toplumunda armă̆an; bireye statü vaad eden, zenginliğini ve yer aldĭ̆ toplumsal sinifi gösterme şansl taniyan, geçmişte siradan bir nesneyken artık paha biçilemez bir nesneye dönüşmüş̧tür" (Ateş 2013, 97). Günümüz koşullarının paha biçilmez nesnesi olan armağan; armağanlaşma eylemi ile sınıftan sınıfa, kişiden kişiye, kültürden kültüre aktarılır ve bu aktarım temelinde birçok duyguya, eyleme sahiplik yapar. Sakarya’ya (2006) göre armağanlaşma geleneğindeki bu içerikler almak, vermek, karşılığını götürmek gibi birbirini takip eden eylemlerden ve gönüllülük, cömertlik, zariflik, yaratıcılık gibi nitelendirilen çeşitli duygulardan oluşmaktadır. Godbout (2003) armağan verme ile karşı tarafa bir duygu vermenin aynı olduğunu belirterek bu duygulara karş111k verme, aktarma, elinde tutma, sahip olma, iştah, bencillik, merhamet ve cömertlik gibi hissiyatları da eklemektedir. Armağanlaşmanın bu içeriğinden sonra artık sunulan ya da kabul edilen armağanların geleneksel pratiklerdeki saflığından çok, bir konum, bir örtük mesaj ya da bir kimlik göstergesi olarak algılandığı daha karmaşık bir süreç yaşanmaktadır. Nitekim Özdemir (2008) de armağanlaşma geleneğinin sosyal yaşamı meydana getiren ve ayakta tutan karmaşık bir sistem olduğunu belirtir. Armağanlaşmanın içeriğindeki karmaşanının nedenlerinden birinin karşılıklılık esası olduğunu belirtmek mümkündür.

Mauss (2005) insanların armağan ilişkilerinde gösterdiği karşllık vermeyi reddedememe, armağanları kabul etmek zorunda hissetme veya armağan verme davranışlarından hareketle irdeler. Bu bağlamda armağanlaşmanın âdeta kişiler arasında sözsüz, informal bir anlaşma olduğunu belirtmek mümkündür. Mauss'un (2005) gösterdiği ve Bataille’nin (1999) güçlü biçimde desteklediği gibi, armağanlaşma konusundaki bu sessiz, sözsüz anlaşmanın temelinde metaların adeta canlı bir gücü olduğu ve bir anlamda karşılık verme zorunluluğu ürettiği 
düşünülmektedir. Mauss'a göre (2005) insanların bu davranış1 göstermelerine neden olan ilk unsur ekonomik içeriklidir. Armağanlaşmanın ekonomik işlevine dayanan bu yorumun ardından armağanlaşmaya ilişkin ikinci yaklaşım "yerli yorum” olarak adlandırılmaktadır. Bu yorumun temel savunusu kişilerin kendilerine verilen armağanın bir ruhu olduğuna inanması ve kişiye armağan vermeyi kendinden bir parça vermekle eşleştirmesidir. Armağanlaşmaya ilişkin üçüncü yorum ise Levi-Strauss'un mübadeleci ve yapısalcı yorumudur. Ona göre armağanlaşma söz konusu olduğunda Mauss'un (2005) kurduğu vermek, almak ve karşıllğında vermek eylemlerinden oluşan eylemler geçerli değildir. Strauss (2010) armağanlaşmaya ilişkin sadece bir zorunluluk olarak değiş tokuş eylemini kabul etmektedir. Armağanlaşma eylemini mübadele ekseninde değerlendiren bir diğer kişi de Derrida'dır (2005). Ona göre bir mübadele biçimi olarak armağan vermek ve zaman vermek arasında ciddi bir ilişki bulunmaktadır. Bu noktada insanlar arası ilişkilerin çoğunu mübadele kategorisinde ele alan Simmel'in ve mübadeleyi değiş-tokuş kuramı ile irdeleyen Homans'ın fikirlerine yer vermek yerinde bir çaba olarak görülmektedir. Simmel'in temel yaklaşımına göre tek taraflı olduğu düşünülen eylemler bile karş111kl11ık içermekte ve çoğunlukla bu karşl1ıkl11ığın içeriğini ekonomik mübadele, karş11ıklılık oluşturmaktadır. Bu karşılıklılığı Kadığlu (2014) bireyin karşısındakine armağan verirken onu hoşnut etmenin yanında, kendisini de tatmin etme arayışından hareketle açıklamaya çalışır. Bu bağlamda armağanlaşmanın içeriğinin bir değişim geçirdiğini belirtmek mümkündür. Dolayısıyla armağanlaşma pratikleri de değişen koşullar, kültürel normlar ve medeniyetler boyunca farklılaşmaktadır. Bu farklılaşma armağanlaşmanın hem anlamı hem de muhteviyatı açısından karşımıza çıkmaktadır. Simmel'e göre mübadele şeylerin nitel ve nicel özelliklerinin sonucu değildir, ona göre mübadelenin hem kendine özgü bir sosyolojik yapısı hem de bireylerin yaşamının asıl biçim ve işlevini oluşturan bir içeriği bulunmaktadır. Bu bağlamda hem bir mübadele biçimi hem de sosyal bir davranış olarak değerlendirilebilecek armağanlaşma pratiklerinin toplumsal davranış temelinde çözümlenmesi konusuna Homans'ın katkıları büyüktür. Öncelikle sosyal davranışı "en az iki kişi arasında, elle tutulur veya tutulmaz ve az veya çok ödüllendirici veya değerli faaliyet alışverişi” (1961, 13) olarak tanımlayan Homans'1n tanımından hareketle armağanlaşmayı hem ödüllendirici hem de değerli bir faaliyet olarak tanımlamak mümkün görünmektedir. Nitekim Homans'ın (1961) öncüsü olduğu değiş tokuş kuramına göre armağanlaşma ile, davranışın karşıllı beklentisi güdülenmekte, insanların çeşitli ilişkilerindeki faydacılık, yararcılık ölçütleri okunmaktadır. Ayrıca armağanlaşma ile toplumsal etkileşimin duygusal, ekonomik ve sosyal içerikli değiş-tokuşlara dayanan içeriği ortaya çıkmaktadır.

Akay’a (2016) göre armağanlaşma kültüründe yaşanan değişimin sebepleri arasında kapitalizm önemli bir konumdadır. Ona göre kapitalizmin ürünlere ait artı değeri kendine çevirerek tek elde toplama çabası armağanlaşmanın geleneksel sistemi ile zıttır. Benzer bir şekilde Ateş’e göre de geleneksel armağanlaşma sisteminden kopuşun ilk adımı ticaret ve paranın kullanımı ile ikinci adımı ise modern düşüncenin ivmelendiricisi olan kapitalist sistem ile gerçekleşmiştir (2013, 57). Belk (1977) de armağanın bu durumuna değinerek armağanlaşmanın kişiler arası ilişkilerdeki belirleyici gücüne vurgu yapmaktadır. Bu noktada armağanlaşmanın karşılıklı11ğının bir diğer boyutu ortaya çıkmaktadır. Bu aşamayı Saad (2011) "yakın bağları güçlendirme" olarak değerlendirmiştir. Ona göre armağanlara ilişkin yapılan harcamaların temel belirleyicisi ilişkilerin yakınlığıdır. Bu doğrultuda daha yakın bağları güçlendirmek isteyen ya da bu yakın bağ kabul eden kişiler için bedeli daha yüksek olan armağanlar tercih edilmektedir. Bu sistemin kişiler arası ilişkileri de metalaştırdığ 1 belirtilebilir. İnsel'e (2003) göre bu süreçte dolaylı yoldan ilişkilere de bir değer biçilmeye başlanır, her şey piyasa ekonomisinin bir parçası haline gelir. Ona göre yüz yüze ve sürekliliği olan ilişkileri ve bu ilişkilerin toplumsal varoluşunu düzenleyen armağanlaşma pratiği pazar ekonomisinden önceki dönemlerde kalmıştır $(2003,11)$. 
Saad'a (2012) göre kapitalizm armağanlaşma üzerinde etkin olmuştur. Bu doğrultuda armağanlar verilmesine neden olması için üretilen sayısız olayla yetinmeyen kapitalist odaklar ve pazarlama profesyonelleri, kutlama merkezine odaklanan birçok yeni armağan verme durumu yaratmış ve bu durumları yaratırken diğer kültürlerdeki armağanlaşma şekillerini de aktarmaya, bir nevi bu durumun da ticaretini yapmaya başlamışlardır. Hyde'ye göre ise ülkeler arası ticaretin gelişmesi ile birlikte armağanın hem ruhu yok olmaya başlamış hem de mübadele ilişkileri kişileri birbirine bağlama işlevinden uzaklaşmıştır. "Armağanın ruhu yok olduğunda armağanın tarafları arasındaki ilişkinin yerini borçlu ile alacakl arasındaki faiz almaktadır" (2008, 72). Godbout (2003) da armağanlaşmanın toplumsal ilişkilerin temelinde yattığını belirterek, temel amacın hem kişinin kendisini sürekli "borçlu” hissetmesi hem de özne ve nesnenin birbirinden ayrılmaması olduğunu söylemektedir. Dolayısıyla bir meta olarak ederinden çok armağanın bir ruhu olduğuna inanılan dönemlerin geçmişte kaldığı belirtilebilse de özel ve yakın ilişkilerde devam eden armağanlaşma geleneği kapitalist sistemin duyguları bile metalaştıran boyutunu biraz esnetmektedir. Hatta Demez'e (2011) göre hâkim kapitalist toplumlar içinde armağanlaşma pratikleri "bireylerin duygusal olarak nefes aldlkları" bir alan olarak değerlendirilmektedir. Birekul'a göre ise her ne kadar armağanlaşmanın içeriği değişse de armağanlaşmanın kültürel boyutlarının ilk insanlardan günümüze süregelen bazı ortak noktaları da bulunmaktadır. Ona göre armağanlaşma verme, alma ve karşılıklı etkileşim gibi bağlamlarda değerlendirildiğinde ilk benzerlik mübadele, diğeri armağanlaşmanın bir güç gösterimi ve prestij ifade eden içeriği ve son olarak armağanlaşmanın geçmişten günümüze sahip olduğu kutsalın varlığıdır $(2014,10)$. Bu bağlamda günümüzde de armağan almanın da armağan vermenin de kişiye atfedilen değer açısından bakıldığında "kutsal” karşılanabilecek, toplumsal dayanışmanın örneği olarak değerlendirilebilecek bir içeriği bulunmaktadır.

Armağanın toplumsal dayanışmanın kaynağı olduğunu savunan görüşe göre armağanlaşma eylemi sayesinde toplumsal ilişki süreklilik kazanmakta, armağan alanın bir süre sonra armağan götürmesi insanlar arasında oluşan bu bağın kopmasını engelleyen bir unsur olarak karşımıza çıkmaktadır. Akay'a (2016) göre armağan ve karşı armağan, bir toplumsal döngüyü yaratırken bu döngü de toplumsal bağın kurulmasını ve devamlılığını sağlamaktadır. Bu devamlılık sayesinde kültür, beğeni, duygu ve algılanması umulan çeşitli mesajlar da karşı tarafa aktarılmaktadır. Dolayısıyla armağanın hem birleştirici hem toplumsal hem de sosyal bağları sağlamlaştıran bir konumu vardır. Demez (2011) ise armağanın toplumsallığına dikkat çekmektedir. Ona göre bireysel bir eylem olarak başlayan armağanlaşma belirli toplumsal kurallar, gelenekler çerçevesinde yapılandığı için toplumsal bir içerik kazanmaktadır. Mauss'a (2005) göre de verilen armağan toplumsal bir içerikte değerlendirilirken, armağanlaşma aracıllğı ile kurulan toplumsal iletişim önemsenmektedir. Bu bağlamda armağanlaşma sürecinin bir kod açımını da beraberinde getirdiği belirtilmelidir. Armağanlaşma sahip olduğu gizli dil sayesinde kişilerin kendileri için ayırdıkları zaman, emek ve bütçeden hareketle ilişkilerin anlam ve önemini çözümler. Bu ilişkilerin bir diğer boyutu da Simmel'e (2009) göre armağanlaşmanın bir sonucu olarak görülen prestijdir. Bu sayede insanların kendi etki alanlarını yine kendilerinin oluşturduğu yorumlanabilir. Armağanlaşmanın bir dili olarak gücün gösterimini Offer (2003) "itibar ekonomisi” kavramı ile açıklamaya çalışırken, armağanlaşmayı bireysel ve sosyal alışverişin bir ürünü olarak itibarın tatmininde önemli faktör olarak değerlendirmektedir.

Çalışma konusu açısından değerlendirildiğinde; dünya genelindeki diğer kültürlerde olduğu gibi Türkiye'de de annelik ve çocuk ekseninde birçok geleneksel ritüel, kutlama ve armağanlaşma pratikleri gerçekleştirilmektedir. Bu kutlama ve armağanlaşma pratikleri incelendiğinde; bu pratiklerin hem geleneksel hem de modern uygulamaları içeren pratikler olduğu gözlenmektedir. $\mathrm{Bu}$ doğrultuda günümüzde hem lohusa, ilk diş ve ilk yaş armağanları gibi geleneksel 
kutlama ve armağanlaşma pratiklerinin sürdürüldüğü hem de gender partileri (cinsiyet partileri), baby shower partileri, hastane odası süslemeleri, altı ay kınası ve doğum günü hamamı gibi modern kutlama örneklerinin gerçekleştirildiği belirtilebilir.

\section{Annelik ve Yeni Doğan Bebekle İlgili Ritüel, Kutlama ve Armağanlaşmaya İlişkin Gele- neksel Uygulamalar}

Toplumsal yaşama ilişkin değer ve normların ilk öğrenildiği yer olarak aile, tüketim pratiklerinin de deneyimlendiği, benimsendiği, şekillendiği mikro düzeyde bir tüketim birimi olarak karşımıza çıkmaktadır. Ailede benimsenen tüketim pratikleri kadının rol ve sorumlulukları üzerinde dikkate değer bir etkiye sahiptir. Bocock'a göre erkekler, eşlerini ve kız evlatlarını, zenginliklerini sergileyebilecekleri araçlar olarak kullanmaktadır (2009, 27-28). Armağan tüketimi özelinde de benzer bir perspektif ile Godbout armağan dünyasını kadınların özel alanı olarak nitelerken; kadınları hediyelerden, hediye ambalajlamaktan sorumlu tutar ve ona göre kadının kendisi de başlı başına bir armağandır (2008, 472). Hurdley (2007) ise armağanlaşma ilişkisini gündelik hayatta, özellikle oturma odasında sergilenen metalar bağlamında ele aldığı çalışmasında armağanın daha çok kadınla ilişkilendirildiğini vurgulamıştır. Bourdieu (2015) armağan ve cinsiyet ayrımı arasındaki ilişkiyi özel alandaki iktidar şekli ile bağdaştırırken; erkeklerin evlilik hayatındaki simgesel iktidarını koruduklarını belirtmektedir. Ona göre evlilik stratejilerinde erkekler özne, kadınlar ise bu mübadele ilişkisinde nesne olarak konumlandırılmaktadır. Kadının armağanlaşma dünyasındaki bu konumu onu sektörün "hedef tüketicisi" haline getirirken, yaşam serüveni içinde edindiği farklı roller ürün ve hizmetlerin yeniden yapılandirilmasına sebep olur.

Lohusa Ziyareti: Türkiye'de yeni doğum yapmış kadına lohusa denmekte, ayrıca "emzikli”, "nevse", "doğazkesen”, "loğsa” gibi kavramlar da yeni doğum yapan kadını tanımlamak için kullanılmaktadır. Geleneksel kültürümüzde lohusalığın belli bir süresi vardır. Bu süre kimi kültürlere göre kırk gün, kimilerine göre yatakta geçirilen zaman, kimilerine göre de emzirme eyleminin devam edişine göre ölçümlenmektedir. Lohusayı ziyaret etmenin de geleneksel uygulamalarda belli zaman dilimlerine bölündügünü belirtmek mümkündür. Genellikle doğumu takip eden ilk haftada "göz aydın" ya da "hayırlı olsun" ve ya "Allah analı babalı büyütsün” ziyaretleri, sonraki hafta ise "hatır sorma" ziyaretleri gerçekleşmektedir. Tunç (2002) ise lohusa ziyaretine eli boş gidilmemesi gerektiğini belirterek, bu ziyaretlerde yakın akraba ve arkadaşların bebeğe altın, ahbapların ise bebek için el örgüsü ürünler, anne için de oyalı havlu kumaş gibi armağanlar getirdiğini belirtmektedir. Alınan bu hediyelere karş1lı lohusa evinde gelenlere herhangi bir armağan verilmemekte, sunulan yemekler, tatlilar ve özellikle "lohusa şerbeti" denen baharatlı ve tatlı içecek ikram edilmekte, bebeği ve anneyi tebrik etmek için gelen misafirlerin konforu ve iyi şekilde ağırlanması gözetilmekteydi.

Diş Bulguru (Diş Hediği, Diş Buğdayl): Çocuk gelişimi açısından; diş çıkartmak hem yeni bir evre hem de çocuğun sağlıklı bir şekilde büyümeye devam ettiğinin bir göstergesi olarak değerlendirilebilir. Haliyle bu evre hem geleneksel hem de modern uygulamalarda kutlamaya değer görülmektedir. "Diş bulguru, diş hediği, diş buğdayl, diş aşı, tiş çırna gibi isimler alan" (Gönüllü 2000, 31) bu kutlamada çıkan ilk diş hem çıkacak olan diğer dişlerin hem de bebeğin yakında çiğnemeye başlayacağının habercisi olarak değerlendirilmektedir. İlk dişin ortaya çıkması ile yapılan bu kutlama Molu’ya (2011) göre yiyeceğin kutsanması, çocuğun rızkının artması, bereketin çoğalması ve dişin sağlam olması gibi alt anlamlar da içermektedir. Sakarya'ya (2006) göre ise fizyolojik bir gelişim evresi olan diş çıkarmanın aile tarafından törensel bir kutlamaya dönüşmesinin sebepleri arasında çocuğun dişlerini zorlanmadan ve sağlıkla çıkarması, çıkan dişlerin hayır dualarına vesilesi olması gibi gerekçeler bulunmaktadır. Dola- 
yısıyla içeriği kutlama, armağanlaşma, ikramlaşma seçenekleri ile dolu olan diş buğdayı kutlamasının temel amacı bebeğin gelişim evrelerinden birini gerçekleştirdiğini duyurmak, bu sevinci akraba ve dostlarla paylaşmak olarak değerlendirilebilir. Sarıtaş'a (2011) göre ise bu kutlamanın amacı bebeğin iyi yetiştirildiğini teyit etmek, topluma doğurganlığının önemini vurgulamak ve bebeğin sağlıkla gelişiminin ilerlemesini dilemektir.

Doğum Günü: Çocuğun ilk yaşının gelmesiyle birlikte yapılan kutlamalarda ev sahibi birçok yiyecek hazırlarken doğum gününe davet edilenler de çocuk için çeşitli hediyeler getirirler. Doğum günü kutlamasının öncelikli ikramı pastadır. Pastanın üzerine dikilen mumlar ise çocuğun yaşını belirtmektedir. Doğum gününde verilen hediyeler incelendiğinde bu hediyelerin hem çocuğa yönelik olması hem de yadigâr kalma özelliğini taşıyacak olmasının tercih edildiği belirtilebilir.

Sonuç olarak geçmişten bugüne gelmiş geleneksel kutlama ritüellerinin sadece "kutlama" amacı ile şekillendiğini belirtmek mümkündür. Bu ritüeller günümüz koşullarıyla kıyaslandığında tüketimin çok mikro bir düzeyde gerçekleştiği, armağanlaşmanın yönünün sadece kutlamayı gerçekleştiren haneye yönelik olduğu ve armağan algısının ikramlıklardan ibaret olduğu ifade edilmelidir. Annelik ve çocuk ekseninde gerçekleşen modern kutlama ver armağanlaşma pratiklerinde geleneksel uygulamaların yansımalarını görmek mümkündür. Çalışmanın bir sonraki kısmında modern kutlama ve armağanlaşma pratikleri detaylandırılacaktır.

\section{Annelik ve Yeni Doğan Bebekle İlgili Ritüel, Kutlama ve Armağanlaşmaya ilişkin Modern Uygulamalar}

Günümüzde birçok sektörün oluşmasına, gelişmesine ve yeniden yapılanmasına neden olan çocuk ve annelikle ilgili modern kutlama ve armağanlaşma pratiklerinin bazı örnekleri geleneksel uygulamalarla benzerlik gösterirken bazıları geleneksel pratiklerden oldukça farklı bir görünüme sahiptir. Özellikle armağanlaşmanın yönü, içeriği ve yoğunluğu açısından ciddi bir değişim yaşanmaktadır. Geleneksel uygulamaların tamamında armağanlaşma kutlamayı gerçekleştiren aileye yönelik, mütevazi ve çoğunlukla standart bir içeriğe sahiptir. Buna karşılık kutlamayı gerçekleştiren aile misafirlerine herhangi bir armağan sunmazken, hazırlanılan çeşitli ikramlıklar, konukların rahat ettirilmesi, kutlama esnasında mutlu olmaları ev sahibinin verebileceği en büyük armağan kabul edilmektedir.

Günümüzde ise anneler çocuklarının doğum öncesi, doğum ve doğum sonrası aşamalarındaki neredeyse her evreyi kutlamakta ve tebrik etmek için gelen misafirlere çeşitli armağanlar hazırlamaktadırlar. Hatta Clarke'a (2007b) göre annelerin bu davranışı günümüzde çeşitli iş alanlarının oluşmasına ve bu alanlarda muazzam miktarda emek, ticaret, sosyal kaygı ve ilişkinin artmasına neden olmaktadır. Ona göre kültür coğrafyacıları olarak, sosyologlar ve kültür ekonomistleri, çocukların doğum günü partilerinin gittikçe artan sosyal bir tüketim ritüeli haline geldiğini belirtmektedir. "Modern dönemle birlikte toplumsal ilişkileri kurma ve devam ettirme görevini yitiren armağanı; üretilenin satılmasını sağlayan ve bireyi egemen güçlerin çıkarları doğrultusunda tüketime yönlendiren, çıkar hesabına dönüşmüşs soğuk bir araç olarak tanımlamak mümkündür" (Godbout 2003, 18). Artık armağanların kişilerin birbirlerini mutlu etme amacının yanında bireylerin sosyo-ekonomik düzeylerinin, yaratıcılıklarının, estetik algılarının, beğenilerinin somut bir göstergesi olarak algılanmaya başlandığını belirtmek mümkündür. $\mathrm{Bu}$ algıyı geliştiren ve yönlendiren unsurlar düşünüldüğünde akla ilk etapta internet, sosyal medya, gelişen teknoloji, küreselleşme ve çeşitli medya araçları gelebilir. Böylece armağanlaşmanın değişen konumu bu pratiği günümüzde fazlasıyla kullanan bir taraf olarak annelerin de armağana bakışını farklılaştırmıştır. Dolayısıyla özellikle günümüzde 
yaygınlaşan armağanlaşma pratiklerini benimseyen annelerin armağanların taşıdığ1 mesajları önemsediklerini belirtmek mümkündür. Onlar açısından sundukları armağanların sahip oldukları konumun, ekonomik yeterliliklerin, moda algılarının vs. adeta sembolik bir dışa vurumu olarak algılandığı düşünülebilir.

Tüketim, armağan, annelik ve kutlama kavramları arasındaki ilişki ve değişim neticesinde günümüz annelerinin algılarının farklılaştığı düşünülebilir. Annelerin bir kısmı bu değişim neticesinde kutlama ve armağanlaşma pratiklerine yaklaşırken, bir kısmı uzaklaşmış, bir kısmı da sadece geleneksel pratikleri benimsemiştir. Fakat günümüzdeki koşullar incelendiğinde; bu gibi uygulamalarda değişen algıların anneleri güncel kutlama ve armağanlaşma pratiklerini uygulamaya adeta zorladığını düşünmek mümkündür. Hatta adeta bu uygulamalardan hareketle anneler, anneliklerini, statülerini, güçlerini, ekonomik durumlarını gerçekleştirdikleri kutlama ve armağanlaşma pratiklerinden hareketle somutlaştırma eğilimine girmişlerdir. Bu bağlamda “Zorunluluğu yaratan sosyal ağlar içindeki beklentiler ve yatırımlardır" $(2011,90)$ diyen Demez'den hareketle bu durumun anneler üzerinde bir baskı yarattı̆̆ını belirtmek de mümkündür. Clarke’a (2007b) göre günümüzde armağanlaşmayı da içeren parti ve ritüellerin düzenlemesi için uygun armağanların ve temaların seçilmesi, armağanlar arasında bir sosyal dengeyi sağlama çabası muazzam bir baskı oluşturmaktadır. Benzer şekilde armağan verme, Otnes ve arkadaşlarının (1997) çalışmasında annelerde kaygı uyandıran bir unsur olarak değerlendirilmektedir. Clarke'a (2007a) göre de bu gibi kutlamalarda kaygı nesneleri aslında çocuklardan çok anneleridir. Hatta anneler için doğum günü partileri fikirlerini kamuya açıklamak için bir firsat olarak görülmektedir.

Baby Shower Partisi: Miller’a (2010) göre küreselleşmeyle gittikçe belirsizleşen sınırlar kültürel referans noktalarını daha önemli hale getirmektedir. Küreselleşmenin etkisiyle ülkeler arasında kalkan sınırlar farklı kültürleri görünür kıldığı gibi, aynı eylemlere yönelik farklı yaklaşımları da gözler önüne sererken kültürel referans noktalarını da farklılaştırmaktadır. Bu koşullarda hangi uygulamanın hangi kültüre ait olduğunu belirlemek zorlaşırken uygulamalar her kültür tarafında içselleştirilerek sahiplenilir. Böylece farklı kültürlerin çocuk bakımı, annelik ve çocuk yetiştirme pratiklerinden haberdar olunduğu gibi, çalışma özelinde incelendiğinde farklı kültürlerin annelik ve çocuğa ilişkin kutlama ve armağanlaşma ritüelleri de öğrenilmiş olur. Günümüzde annelik ve çocuk ekseninde gerçekleşen kutlamalardan biri olan baby shower partilerini de öncelikle bu perspektif ile ele almak yerinde bir çaba olarak değerlendirilebilir. Nitekim ilgili kutlama Türkiye'de son yıllarda uygulanmaya başlamış ve giderek yaygınlaşmıştır. Bu bağlamda küresel kültür entegrasyonunun somut kanıtı olarak değerlendirilebilecek "baby shower" partilerinin esasen Amerika Birleşik Devletleri'ne ait bir gelenek olduğunu da belirtmek gerekmektedir.

Kutlama ve armağanlaşma ritüellerinin “sınır ötesi” hali Morgan ve Micheals’a (1999) göre fetusları kuşatacak kadar genişlemiştir. Onlara göre baby shower kutlamaları ile daha doğmamış fetus "Hollywood" stili ile cinsiyetlendirilir, isimlendirilir, fotoğraflanır. Hatta onlar bu durumu "fetüs konusunun küreselleşmesi” olarak adlandırmakta ve bu durumun gittikçe yaygınlaştı̆̆ını vurgulamaktadırlar. Byström'a (2015) göre bu durum bebeğe bağlı çok çeşitli tezahürler, uygulamalar ve sosyal anlamların oluşmasına neden olmaktadır. Sanchez'e (2003) göre günümüzde baby shower partilerini annelerin bebeğini karşılama hazırlıklarının sabit elemanları arasında görmek mümkündür. Hem sektörün hem de kapitalist süreçlerin etkisiyle anneliğe ilişkin baskın argümanlar annelerin yaşamını, çocuk bakımına ilişkin sahip olduğu nitelikleri sembolik ve ticari nesnelerle örüntülü ve uyumlu hale getirmiştir. Bu durumun bir sonucu olarak, annelerin yeni kültürel olgulara, seçeneklere ve uygulamalara ulaşması kolaylaşmıştır. Hyrciuk’a (2010) 
göre bu koşullar yüzünden anneler, kısa bir süre önce Amerika'ya özel olan ve artık ithal edilen baby shower partilerini kendilerini ifade etme aracı olarak tercih eder olmuşlardır. Bu bağlamda günümüz koşullarında öncelikli olan baby showerın katılımcılara ailenin mevcut konumunu doğru ifade edebilecek şekilde kurgulanmasıdır. Oysa literatür incelendiğinde Amerika patentli olan baby shower partilerinin ilk gerçekleştirildiği dönemlerdeki temel amacı bebeğin ilk ayları için maddi ihtiyaçlarının karşılanmasına bir kaynak oluşturmak, ailenin bebek ile ilgili ihtiyaçları olacak şeyleri edinmelerine yardımcı olmak ve bebeğe ilişkin ihtiyaçları gelen hediyeler aracıllğı ile biriktirmektir (Sanchez 2003; Hryciuk 2010). Dolayısıyla o dönemlerde her ne kadar baby shower sunulan ikramlar, eğlenceler, armağanlar, mekâna ilişkin masraflar, ailenin kişisel hazırlık masrafları (giyim, aksesuar vs.) gibi maliyetlere neden olsa da ekonomik açıdan faydalı ve destekleyici bulunmaktadır. Fakat buradaki temel ekonomik faydanın, katılımcıların doğum için gerekli çoğu şeyi hazır hale getirebilecek armağanlara sahip olacakları kabulü olduğunu belirtmek gerekmektedir.

Üst ve orta sınıf tarafindan öncelikli olarak benimsendiği belirtilen baby shower kutlamaları (Sanchez 2003; Hyrciuk 2010) diğer sınıflar tarafından da sahiplenilmiş ve kültürler içerimlerle uyumlu hale getirilmiştir. Bu uyumlaştırma sürecinde baby shower partisi her kültürde farklı bir şekilde deneyimlenmektedir. Byström (2015) da benzer bir şekilde bu gibi ritüellerin çeşitli medya araçları ile aktarıldığını ve daha sonra kişilerin bu uygulamaları kendi yerel ihtiyaçlarına göre yapılandırıp uyarlayarak bu kültürel anlamda çekirdek tecrübeleri paylaşma ve kendi koşullarıyla annelik yaşantısını kutlama yoluna gitmektedirler. Hyrciuk'a (2010) göre yaşanan bu deneyimler küreselleşmenin bir sonucu olarak değerlendirilebilirse de bu durum kültürel bir homojenleşmeye neden olmaz. Ona göre yerel kültür kalıpları bu etkiyle dönüştürülür, bu sebeple tamamen taklitçilikten bahsetmek mümkün değildir. Tam tersine hâkim kültürel uygulamalarla benzeştirilen baby shower kutlamaları bir yeniden yapılanmanın, kültürle harmanlanmış yaratıcılığın göstergesi olarak kabul edilebilir. Bu bağlamda farklı kültürlere, öykünme, gipta etme ve özenme ya da tam tersi olarak küçümseme toplumsal hayat içinde gözlemlenebilen bir durum olarak değerlendirilmelidir. Örneğin Hürmeriç ve Baban’a (2012) göre Amerikan kültürü kendisini diğerlerinden daha iyi ve üstün görmeye dayalı psikolojik doyum sağladığı için, farklı kültürler tarafindan, üstün bir karaktere sahip olarak nitelenir ve bu durumun bir sonucu olarak taklit edilir. Dolayısıyla gerçekleştirilen baby shower kutlamaları da benzer kaygı ve öykünmeleri içermektedir.

Hastane Süsleme Organizasyonu: Günümüzde karşılaşılan ve yaygınlığı artan bir diğer organizasyon da annenin doğum yaptığı hastane odasının süslenmesine dayanmaktadır. Geleneksel kültürümüzde karşıllğ̣ olmayan bu uygulamada anne ve bebeğin kalacağı hastane odası bebeğin cinsiyetine, annenin talebine göre çeşitli şekillerde süslenerek tebrik için gelenlere ikramlar, armağanlar sunulmaktadır. İkramlar için ayrı bir köşe hazırlanırken, sahip olunan bütçeye göre ikram sayısı, armağan sayısı, bebeğe ve anneye özel olarak hazırlanmış ürün sayısı da değişiklik gösterebilmektedir.

Lohusalık ve Bebek Armağanlart: Modern uygulamalarda doğumu tebrik etmeye gelen kişilere ikramlıkların ya da lohusa şerbetinin yanında ayrıca çeşitli armağanlar sunulduğu gözlenmektedir. Bu kapsamda sunulan armağanların çeşitliliği gibi hazırlanış şekli de maddi imkânlarla doğru orantılıdır. Ekonomik açıdan güçlü olan kişilerin birden çok armağan alternatifi ile organizasyon firması ya da çeşitli kişilere ücret karşı1lı̆̆ bu armağanlar hazırlatılmaktadır. Ayrıca bu armağanlar daha çok bir kutlama eşliğinde sunulurken. Herhangi bir kutlama olmaksızın gelen misafirlere de verilmektedir. 


\section{Doğum Günü Kapsamında Hazırlanan İlk Yaş Hediyelikleri}

Geleneksel kutlamalarla örtüşen ilk yaş kutlamaları, içeriğindeki değişim ve dönüşüm nedeni ile modern kutlama ve armağanlaşma ritüellerine dâhil edilmiştir. Modern uygulamalarda bebeğin ilk yaş kutlaması hazırlıkları aylar öncesinden başlayan bir süreci gerektirmektedir. Bu doğrultuda organizasyon firmaları ile görüşülmekte, konseptler, anne-baba ve çocuğun zevkli bir "kombin" yansıtacak giyecekleri belirlenmekte, ikramlıklar ve armağanlar hazırlanmaktadır. Adeta bir düğün hazırlığını anımsatan bu kutlama için davetiyeler bastırıldı ̆̆ı, fotoğrafçılar tutulduğu, animatörlerden yardım alındığı da gözlemlenmektedir. Dolayısıyla günümüzde oldukça meşakkatli bir çalışmayı gerektiren bir çocuğun doğum günü partisinde bir temanın seçilmesi (Batman, Barbie, Ejderhalar vs.), ideal pastanın yapılması ya da alınması, misafirler için ideal armağanlar seçilmesi, armağan çantaları, yaşla ile ilgili koordine edilmiş oyunlar ve etkinlikler; parti kıyafeti dikme ya da satın alma; süslü kıyafetleri, parti tabakları, bardaklar, şapkalar ve masa örtüleri seçimi; onun istediği parti malzemeleri ve atıştırmalıklar için alışveriş yapmak veya yaptırmak ve en önemlisi, parti konuklarının ve oranlarının doğru ve dikkatli bir şekilde seçilmesi gibi birçok eylemi içinde barındırmaktadır. Clarke’a (2007b) göre bu seçimler, diğer ailelerin geçmişte kullandığ 1 ve gelecekte potansiyel olarak kullanma ihtimalleri olan tercihlerle yoğun ve detaylı bir biçimde karşılaştırılır. Ona göre tam da bu nedenle çocukların doğum günü partileri âdeta işgal edilmekte ve artık partiler sadece yaş belirlemedeki bariz rolünün yanında belli bir zaman içinde bir tüketim çeşidi haline gelmektedir. Doğum günleri kapsamında gerçekleşen bu çeşitli eylemlerin yarattığı tüketim dünyası Clarke’a (2007b) göre günümüze özel annelik türlerinin yaratılmasında da kullanılmaktadır. Bu partilerdeki eylemlerden hareketle anneler “özenli”, “titiz”, “sağllkll”, “zengin”, “modaya uyan” vb. şekillerde nitelendirilmektedir. Annelerin bu kutlamalarda tercih ettikleri armağanları ve katılımcılara sundukları ortamı kendileri, seçimleri hakkında ortaya koydukları ipuçları olarak değerlendirmek mümkündür. Bu kutlamada armağan olarak fidanlar, canlı balıklar, kurabiyeler, magnetler, anahtarlıklar, sabunlar, lavanta keseleri, tohum bombaları gibi çeşidi artırılabilecek ürünler tercih edilmektedir

Pasta Patlatma: Çoğunlukla çocuğun ilk yaşında gerçekleştirilen bu kutlama için aslında herhangi bir yaş limiti olmadığını belirtmek gerekmektedir. İlk yaşta yapıldığında bebeğin kıyafetleri değiştirilir ve doğum günü pastasının bir prototipi bebeğin önüne konur. Bebek pastayı "patlatırken" fotoğrafları çekilir, ailesi ve diğer misafirler alkışlar, kahkahalar, müziklerle ona eşlik eder. İlk yaş dışında da pasta patlatma kutlamasının muhteviyatı benzerdir. Çocuğun pastayı eliyle yemesi, parçalaması beklenir. Yaş biraz daha büyüdükçe beklenmeyen bir anda bir kişinin doğum günü pastasını yeni yaşını kutlayan kişinin suratına yapıştırması da "pasta patlama" ismi ile anılmaktadır.

\section{Araştırmanın Yöntemi}

Nitel araştırma yöntemini ile gerçekleştirilen çalışmanın genel çerçevesi, benimsenen nitel yöntem sebebi ile yorumsamacı yaklaşım ile şekillendirilmiş ve bu şekilde "harcı insan olan" (Williams, 1999) sosyal olayların birbiriyle örüntülü ve iç içe geçmiş (Yıldırım \& Şimşek 2011) hali aydınlatılmaya çalışılmıştır. Weber'in sosyolojiyi toplumsal ve sosyal içerikli eylemlerin "yorumcu olarak anlaşılması" şeklinde konumlandırması da hermeneutik yaklaşımı akla getirmektedir. Bu bağlamda çalışma kapsamında toplumsal olarak inşa edilip öznel olarak deneyimlenen anneliğin kutlama ve armağanlaşma pratikleri ile iç içe geçtiği noktalar aydınlatılmaya çalışılmıştır.

Yorumsamacı yaklaşımın temel savunusu gerçekliğin somut ve objektif olamayacağı bu 
bağlamda da ancak subjektif verilere, insan bilincinin derinliklerine, öznel deneyimlere odaklanılarak olguların, gerçekliğin çözümlenebileceği düşüncesidir. (Burrell \& Morgan 1979; Leblebici 2008; McKenna et al. 2011). Yorumsamacı yaklaşımın bir sonucu olarak çalışmada bilginin göreli olduğunu savunan anti-pozitivist bir bakışı benimsenmiştir. Bu doğrultuda öznel bir deneyim olmasına karşın toplum tarafından şekillenen annelik deneyimini kutlama ve armağanlaşma pratiklerinin nasıl etkilediğini anlama girişiminin nitel araştırma teknikleriyle daha olanaklı olacağı düşünülmüştür. Rubin ve Rubin'e (1995) göre niteliksel metodoloji, olgu fenomeninde bulunan kimlik gibi içsel ve kişiler arası dinamiklerin incelenmesinde özellikle yararlıdır. Çünkü veri üzerine kantitatif araştırmalardan daha az kısıtlama koyar ve bireysel tecrübenin nüanslarının yüzeye çıkmasına olanak tanır. Laney’e (2014) göre ise nitel araştırmanın sağladığı satır satır analiz, hem verilerin neler içereceğini daha net bir şekilde belirlemeye olanak sağladığı, araştırmacı tarafından ise önyargıların askıya alınarak elde edilen verileri büyütme fırsatı sağladığı için bilimsel araştırmalarda yaşamsal öneme sahiptir.

Çalışmanın katılımcı grubu 50 anne ile sınırlandırılmıştır. Katılımcı annelere çalışma amaçları doğrultusunda, gerçekleştirilebilirlik, ulaşılabilirlik, uygunluk ve gönüllülük (Creswell, 2016) açılarından daha elverişli ve görece daha yoğun etkileşimler sağlanabileceği düşüncesi ile olasılığa dayalı olmayan örnekleme türlerinden kartopu (zincirleme, katılımcı örnekleme de denmektedir) tekniğiyle ulaşılmıştır. Ayrıca çalışmada kullanılan yorumlayıcı fenomenolojik yöntem gereği homojen bir katılımcı gruba ulaşmak hedeflendiği için kartopu örnekleme "amaçll" bir şekilde yapılandırılmış, annelerin refere ettiği katılımcıların öncelikle katılımcı koşullarını sağlayıp sağlamadığı irdelendikten sonra katılımcı anneler listesine dâhil edilmesi sağlanmıştır. Çalışmanın katılımeı grubunu oluşturan annelerin profili; hâkim kutlama ve armağanlaşma pratiklerinden en az birini gerçekleştirmiş olmaları, son doğumlarının üzerinden en çok 3 yıl geçmiş olması, Antalya'da yaşıyor olmaları olmakla birlikte anneler farklı yaşlardan, şehrin farklı bölgelerinden, farklı ekonomi ve eğitim seviyelerinden ve farklı sayıdaki çocuğa sahip kadınlardan oluşmaktadır.

Amaçlı kartopu örnekleme tekniğiyle ulaşılan 50 anne ile derinlemesine görüşme gerçekleştirilmiştir. Görüşmelerde annelerin bir süre sonra ortak bakış açılarının yaygınlaştığı ve verilerin birbirini tekrar ettiği fark edildiğinde, hem zaman, hem katılımcı sayısı hem de elde edilen veriler açısından Hammersley ve Atkinson'un (2007) ifadesi ile “alan tatmini” hissedilmiş ve sürecin doygunluğa ulaştığ düşünülerek derinlemesine görüşme aşaması sonlandırılmıştır.

\section{Araştırma Bulguları}

Çalışma sonucunda elde edilen demografik nitelikli bulgulardan hareketle öncelikle katılımc1ların genel profilleri oluşturulmuştur. Daha sonra elde edilen bulgular kutlama ve armağanlaşma pratiklerinden haberdarlık durumu, bu ritüelleri gerçekleştirme nedenleri ve ilgili pratiklerin yarattığı olası baskıya yönelik olarak üç ana grup şeklinde detaylandırılmıştır.

\section{Katılımcıların Sosyo- Demografik Özellikleri}

Araştırmanın katılımcı grubunu oluşturan anneler yaşları açısından incelendiğinde büyük çoğunluğunun (32 kişi) 30-43 yaş aralığında, kalan (18 kişi) katılımcıların da 25-29 yaş aralığında olduğu anlaşılmıştır. Çocuk sayıları açısından katılımcılar değerlendirildiğinde annelerin yarısının bir, 21 katılımcının iki çocuğu, 4 annenin ise üç çocuğu bulunmaktadır. Katılımcılardan iki çocuğu olduğunu belirten 4 annenin ise görüşme esnasında hamile olduğu anlaşılmıştır. Çalışmaya katılan en genç anne 23 en yaşlı anne ise 43 yaşındadır. Annelerin küçük çocuklarının yaşları ise minimum 4,5 ay, maksimum 3 yaşa kadar uzanmaktadır. İki çocuğu olan annelerin ikinci çocukları ise an az 5 en çok 9 yaşındadır. 
Elde edilen sosyo-demografik verilerden hareketle katılımcıların genel görünümünün çoğunlukla 30-43 yaş aralığında, 3 yaşından küçük en az 1 çocuk sahibi, 2-10 yıl süredir evli, lisans mezunu ve iyi gelir seviyesine sahip annelerden oluştuğunu belirtmek mümkündür. Dolayısıyla çalışma kapsamında elde edilen bulgular kutlama ve armağanlaşma pratiklerinin tüketimi söz konusu olduğunda ortanın üstü bir gelir ve eğitim seviyesine sahip, aktif çalışma yaşamını deneyimlemiş annelerin deneyimlerinden oluşmaktadır.

\section{Annelerin Kutlama ve Armağanlaşma Pratiklerinden Haberdar Olma Durumu ve Ger- çekleştirdikleri Kutlama, Armağanlaşma Ritüelleri}

Çalışmanın bu kısmında annelik ve çocuk ekseninde gerçekleşen kutlama ve armağanlaşma pratikleri bir tüketim unsuru olarak ele alınmış ve bu pratiklerin anneler üzerindeki etkileri araştırılmıştır. Bu bağlamda ilk olarak annelerin bu ritüellerden anne olmadan önceki süreçte haberdar olup olmadıkları öğrenilmeye çalışılmıştır.

Kadınlar anne olduktan sonra anneliğe ilişkin pazarın imkânlarını, hâkim pratiklerin alternatiflerini, anne olunca alınması ve yapılması gerekenleri fark etmeye ve tüketmeye başlamaktadırlar. Örneğin Hogg'un arkadaşlarıyla 2004 yılında gerçekleştirdiği çalışmada hayatta yeni bir role geçiş yapmaya çoğunlukla pazardaki etkileşimin ve yeni role alışmayı kolaylaştıracak tüketimin de eşlik ettiği, bu değişimin de tüketimi artırdığı belirtilmiştir.

Katılımcı ifadelerinden hareketle annelerin konuya yaklaşımlarını üç davranış grubunda sınıflandırmak mümkün olmuştur: İlk gruptaki anneler anne olmadıkları dönemde bu gibi uygulamalardan ya haberdar değil ya da bu uygulamalara karşı sempatik bir bakış içinde değilken, anne olduktan sonra haberdarlıklarında ve uygulamalara bakışlarında olumlu ve ritüelleri sahiplenici, uygulanması gereken pratikler olarak görenler yer almaktadır. Katılımc1 annelerin neredeyse tamamı (45 kişi) bu uygulamalardan hamileliklerinden önce de haberdar olduklarını ve uygulamalara ilgilerinin anne olduklarında artığını dile getirmişlerdir. $\mathrm{Bu}$ düşüncelerini “...biliyordum böyle şeyleri, çoğu arkadaş ve tanıdıklarımın gerçekleştirdiklerine de katıldım ama anne olduktan sonra kendim de gerçekleştirmek istediğim için daha çok ilgilendim diyebilirim” (A.3, 35 yaş), ve “...anne olmadan bu kutlamalar duyuyordum ama çok sicak değildim. Anne olduktan sonra işin rengi değişti tabii ki, hepsine olmasa da bir klsmina daha sıcak bakmaya başladım” (A.9, 32 yaş) şeklinde ifade etmişlerdir. Katılımcıların ifadelerinden hareketle kişilerin annelik rolünü üstlenmeleriyle birlikte armağanlaşma ve kutlama pratiklerine ilgileri arttığı gibi daha pozitif baktıkları da söylemlerinden anlaşılmıştır. İkinci gruptaki anneler uygulamalardan haberdarken ve konu dâhilindeki çeşitli davetlere aktif olarak katılmış, henüz kendileri anne değilken bu gibi pratikleri gerçekleştirme hayalleri kurmuş ve anne olduktan sonra da kendi tanımlarına göre "fazlasıyla" bu uygulamaları gerçekleştirmişlerdir. Üçüncü grubu oluşturan katılımcıların ortak noktası ise birden çok çocuğa sahip oldukları için bu gibi uygulamalardan haberdar olan anneler olmalarıdır. Bu grup da kendi içinde üç alt grupta incelenebilir: İlk grupta anneler ilk çocuklarında bu gibi uygulamaları yapmamış ya da yapamamışken ikinci çocuklarında bu uygulamaları fazlasıyla sahiplenerek çoğu ayrıntıyı gerçekleştirmişlerdir. İkinci grubu oluşturan anneler ise ilk çocuklarında bu gibi pratikleri gerçekleştirmiş fakat ikinci çocuklarında zaten daha önce yaşadıkları, heveslerini aldıkları için diğer çocuklarında gereksiz bularak hiçbir uygulama yapmamış ya da sadece kendi annelerinin, anneannelerinin gerçekleştirdikleri geleneksel uygulamaları tercih etmişlerdir. Üçüncü gruptaki anneler yine birden çok çocuklu ve ilk çocuklarında bu gibi uygulamaları gerçekleştiren katılımcılardan oluşmuştur. Bu gruptaki anneler ise uygulamaları gereksiz, maddi açıdan külfetli görseler de sadece ilk çocuklarına yaptıkları ve "adil, adaletli" olma idealleri yüzünden diğer çocuk veya çocukları için de aynı oranda gerçekleştirdiklerini belirmişlerdir. 
Günümüzde bu doğrultuda gerçekleşen kutlama pratiklerinin oldukça çeşitli olduğu belirtilmelidir. Çalışma kapsamında baby shower, hastane odası süsleme, lohusa mevliti, diş buğdayı, ilk yaş kutlaması, pasta patlatma kutlamaları konusunda katılımcıların fikirleri alınmıştır. Çalışma kapsamında en sık gerçekleştirilen kutlama ritüelleri sırasıyla ilk yaş doğum günü, lohusa mevliti, diş buğdayı ve hastane odası süslemesi kutlamalarıyken, en az gerçekleştirilen kutlamalar 6 ay kınası, baby shower ve pasta patlatma olmuştur. Çalışma esnasında yeni kutlama ritüeli olarak katılımcılardan öğrenilen iki kutlama tespit edilmiştir. İlki gender (cinsiyet) partileri ve ikincisi de doğum günü hamamları olmuştur.

“... ben baby shower yaptım, hastane odast da süslettim, lohusa mevliti zaten yaptık, diş çıkınca da kutladık tabii ve son olarak ilk yaş doğum gününü kutladık o kadar şimdi ikinci yaşa hazırlanıyoruz. Ama çok arttı bu tarz şeyler, ben yetişemiyorum artık neyi kutlayacağıma aslında mesela bir hafta kadar önce gender parti diye bir şeye gittik ailece. Baby shower dan önce yapulan bir şeymiş bu bebeğin cinsiyetini anne de baba da herkesle birlikte, bir parti eşliğinde ögrreniyorlar. Bana ilginç geldiğ $i$ için anneyle konuştum nasıl bir şey diye. İkinci çocuk düşünüyorum, aklımda kalsın istedim. Doktorla anlaşmışlar önceden doktor da bebeğin cinsiyetinden emin olduğunda bunu kapalı bir zarfa koymuş anneye vermiş, sonra parti hazırlikları başlamış. Renklerden hem pembe hem mavi seçilmiş, hediyeler hazırlanmış pasta kesilmeden önce annenin ve babanın ortak kararl olan bir kişinin eline cinsiyetin yazllı olduğu zarf veriliyormuş. Bu kişi de cinsiyeti açıklıyormuş” (A.47, 30 yaş).

“...en son bir arkadaşımın kizı için yaptı̆̆ı "doğum günü hamamı”na katıldım. Itiraf etmek gerekirse aklım durdu, gelin hamamındaki koca gelinin yerine 8-9 yaşlarında bir çocuk koyun o kadar. Geri kalan her şey aynı minik tefler, dansöz klyafetleri, abartılı makyajlar, çocuğun arkadaşlarında da benzer klyafetler... Eğlendim mi? çok eğlendim ama ben çocuğuma yapmam çünkü çocuklar arasında da sonrasında bir yarış, bir rekabet yarattığını düşünüyorum. Çocuklar doyumsuz oluyor" (A.27, 25 yaş).

Katılımcı ifadelerinden hareketle annelik ve çocuk ekseninde gerçekleşen pratiklerin doğasının dinamik olduğu ve sürekli yeni kutlama ritüellerinin ortaya çıktı̆̆ını belirtmek mümkündür. Çalışma kapsamında ele alınan kutlama pratiklerinden en güncel olan baby shower partilerinin günümüzde gittikçe görünür hale geldiği düşünüldüğünde bu gibi yeni uygulamaların da ilerleyen dönemlerde yaygınlaşacağı beklenebilir.

Katılımcı annelerin mevcut kutlama ve armağanlaşma pratiklerini gerçekleştirme sıklıklarına bakıldığında; öncelikle hiç kutlama yapmayan anne bulunmazken katılımcı annelerin tamamının en az bir, çoğunun (35 kişi) ise birden çok kutlama ritüelini gerçekleştirdiği gözlenmiştir. En çok kutlama ritüelini gerçekleştiren annenin 6 kutlama gerçekleştirdiği anlaşılmıştır.

“...benim yapmadiğım kalmadl, daha da olsa onları da yapardım. Çünkü zaten tüp bebek ile bir bebeğim oldu, o da çok zor oldu. Baby shower da yaptım, fotoğrafçı da tuttum, hastane odamı da süsledim, lohusa mevliti yaptım, 6 ay kınası yaptım, diş buğdayı yaptım, ilk yaşını zaten tartışmasız yaptım. Bir tanecik çocuğum var, bir daha anne olma şansım da yok. O yüzden ben de çocuğum da her şeyi yaşayalım istedim. Hepsine ayrı renk, ayrı konsept seçtim, evet çok para harcadım, yoruldum hatta zaman zaman da eleş̧irildim ama pişman değilim. Hatta bu aralar 
cinsiyet partisi gibi bir şey çıktı ona yetişemedim artık ama bizim oralarda ilerleyen yaşlarda çocukların doğum günlerini hamam da kutlayanlar var kızım bir daha büyüsün onu da yapacağım” (A.31, 42 yaş). "...ne duyduysam yaptım neredeyse, kim yapmişsa da hepsine katıldım. Sonuçta bir daha anne olup olmayacağımın garantisi yok ki, anneliğimi keyifle yaşamanin yollarindan biri bence bunlar. Hamileyken baby shower yaptım ve çok eğlendim, kocaman karnımla çok da iyi hissettim. Doğum yapacağım gün hastane odasını da süslettim, fotoğrafçı da tuttum kızıma 6 ay kınası da yaptım, pasta da patlattım, ilk yaşını da yaptım, her yaşını da kutlamayı düşünüyorum. Bence bunlar eğlenceli şeyler" (A.33, 37 yaş).

Yukarıdaki örneklerden izleneceği üzere bazı annelerin çocuk ve annelik ekseninde gerçekleşen ritüellerin neredeyse tamamını gerçekleştirdiklerini ve gerçekleştirmekten de mutlu olduklarını belirtmek mümkündür. Buna karşın bazı katılımcıların da ritüelleri uygulamayı tercih etmedikleri hatta eleştirdikleri belirlenmiştir.

“... Ben bunların hiçbirini yapmadım çünkü gereksiz bir tüketim olarak görüyorum. Yani günümüzdeki abartıl şekilleri ile yapmadım. Lohusa mevlitine de, diş buğdayına da, ilk yaş kutlamasına da birinci derece yakınlarımı çağırdım sadece. Çünkü çocuk olunca masraf çok artıyor bunlara verilecek paraları daha farklı şekilde değerlendirebilmeniz gerekiyor diye düşünüyorum. Toplu bir kutlama yapmadım. Gerçekten hayatımda ve yanımda olanlarla paylaştım her şeyi. Her aşamada kutlamalarım mütevazi oldu” (A.10, 37 yaş).

Bu noktada belirtmek gerekir ki; görüşlerine başvurulan katılımcıların farklı sosyo-demografik özelliklere sahip olmaları farklı görüşleri benimsemelerinde etkili olmaktadır. Ritüellere yaklaşım konusunda payı olduğu düşünülen bu farkl11ıklar; çocuk sayısı, eğitim düzeyi, çalışma durumu ve evlilik süresi olarak şekillenmektedir.

Tıpkı kutlama ritüellerinde olduğu gibi armağanlaşma pratikleri konusunda da annelerin tercihleri ve gerçekleştirdikleri uygulama sayıları çeşitlilik göstermektedir. Annelerin hepsi en az bir armağanı kutlamalarda katılımcılara dağıtmışken, en çok armağanlaşma gerçekleştiren anne tüm kutlamalarla toplam 16 çeşit armağan dağıtmıştır. Çalışma kapsamında gerçekleştirdikleri kutlamalarda hiç armağan dağıtmadığını belirten annelerin çocuklarının adına özel olarak yapılmış çikolata, kurabiye gibi gıda malzemelerini ikram ettikleri anlaşı1mıştır. Bu anneler "hiçbir şey yapmadı olmasın" diye bu ikramlarda bulunduklarını ifade etmişlerdir. Örneğin “...sadece doğumdan sonra doğum şekerleri oluyor ya onlardan hazırladik bi de gelenlere çikolata falan ama onun dışında hazırlamadım sadece doğumda işte doğumdan sonra ziyarete gelenlere vermek için, en azından onu yapmış olayım değil mi” (A.14, 41 yaş).

Annelerin çoğunlukla tercih ettiği armağan türleri arasında ilk sıralarda; magnet, anahtarlık, kokulu taş, kitap ayracı, koku şişesi, kalem ve kutlama çeşidine göre tesbih, yasin kitabı, kese yer almaktadir.

“...doğduğunda magnet yaptırdık mevlit te de tesbih ve yasin kitabı yaptırdlk” (A.8,28 yaş).

“...verdik tabii magnet tarzı yaptırdık ikisinde de böyle kokulu bi de küçük cevşenli tesbih verdik mevlitte. İlk yaşına da şimdi iki ay kaldı yaşına girmesine ya baklyorum arkadaşlardan kutlamalardan falan filan işte örnek alarak şu an kesin bi karar vermedim ama yapacağım, herke- 
sin yaptığından farklı şeyler yapmak istiyorum ama çok araştırmaya vaktim olmuyor, araştırtyorum" (A.23, 29 yaş).

Annelerin tercih ettiği armağan türlerinde armağanların ekonomik maliyetleri ya da işlevsel olup olmamalarından ziyade görece manevi değeri daha yüksek objelerin armağan olarak tercih edildiği görülmektedir. Örneğin;

“...ben gerçekleştirdiğim her kutlama sonrasında verdiğim armağanın çocuğumdan izler taşımasına özen gösterdim açıkçası. Illkinde onun hastanedeki el ve ayak izlerini küçülterek, güzel bir dörtlük yazıp bir kitap ayracına dönüştürdüm, diş̧inde klzım ısırdı̆̆ ilk şeyin kalıbını şeker hamurlu kurabiyelere çıkarttım, ilk yaşında da bebeğimin resminin olduğu çerçeveler verdim. Bunların hepsi çocuğumdan şeyler, çok anlamlı şeyler, maddi olarak bir şey tutmuyor yoksa, ben o arkadaşlarımın evine gittiğinde çocuğumdan bir iz görmekten çok hoşnut oluyorum. Onlara armağan ettiğim şeyler sayesinde hatırlanıyoruz, bir bağ oluyor sanki aramızda" (A.30, yaş 31).

$\mathrm{Bu}$ bağlamda annelerin sundukları armağanlara aynı zamanda bir anlam yüklediği belirtilmelidir. Yaşanan armağanlaşma sayesinde bu ritüellerde tören haline gelen tüketime konusu olan armağanların da kategorileşen bir içeriği bulunmaktadır. Dolayısıyla armağanların içerdiği sembolik anlamlar da kutlamalara katılanlar tarafindan çözümlenir. Bu noktada Mauss'un (2002) armağana ilişkin fikirleri akla gelmektedir. Ona göre armağan veren sağlayıcı, sadece bir önemi değil, kendisinden bir parçayı da vermiş olur, armağan, vericisinden ayrılamaz. Bu bağlamda kutlamalara gelenlere verilen armağanların hem bir ruhu vardır hem de anneler bu armağanlara çeşitli şeyler yansıtırlar. Örneğin estetik zevkleri, yaratıcı yönleri, ekonomik güçleri, hassas düşünceleri bunlardan birkaçı olarak düşünülebilir. Haliyle armağanların hem sosyal içeriği hem de sosyal bağ yaratan işlevi katılımcı ifadelerinden hareketle tespit edilmiştir.

\section{Annelerin Kutlama ve Armağanlaşma Ritüellerine Bakışına ve Bu Pratikleri Gerçek- leştirme Nedenlerine İlişkin Bulgular}

Çalışmanın bu kısmında katılımcıların ilk olarak günümüzde yaygın ve hâkim olan bu ritüellere bakışı irdelenmiştir. Bu bağlamda annelerin pratiklere ilişkin fikirleri, uygulamaların gerekliliğine ve işlevine ilişkin düşünceleri ve uygulamalara yönelik olumlu ve olumsuz eleştirileri çözümlenmeye çalışılmıştır.

Derinlemesine görüşmenin diğer aşamalarında olduğu gibi bu aşamada da annelerin fikirlerini belli gruplara ayırmak mümkündür. Öncelikle annelerin neredeyse tamamının (44 kişi) bu uygulamaları gereksiz gördükleri bilgisine ulaşılmıştır. Bu görüşe çoğu annenin katılmasına rağmen katılımcı anneler arasında kutlama ve armağanlaşma pratiklerini uygulamayan annenin bulunmaması dikkat çekicidir. Annelerin neredeyse tamamı bu uygulamaları gereksiz görse de bu ritüellerin bir kısmını gerçekleştirmiştir. Sadece uygulama sıklığı, sayısı, şekli ve uygulamaların yapılış nedenlerine ilişkin görüşleri bakımından birbirlerinden ayrılmışlardır. Örneğin bazı anneler bu uygulamaların geleneksel şekillerini uygulamayı uygun görürken kendi annesi, anneannesi ne yaptıysa aynısını gerçekleştirmiş, bunların dışında kalan anneler yeni ortaya çıkan uygulamaları "gereksiz bulduklarını" belirtmiş̧lerdir.

“...ben hiçbir şey yapmadım diyebilirim yani günümüzdeki şaşalı şeylerle klyasladı̆̆ımda ona varıyorum. Yani yaptığım şeyler bizim annelerimizin, ninelerimizin yaptıklarından çok fazla olmadı. Hastane odası falan süslemedim, bana fazlası gereksiz geliyor neyi süsleyeceğim zaten 
ăgrım var, acım var, bir an önce çıkmak istiyorum. Bir tek çikolata, badem şekeri ve lohusa şerbeti yaptırdım o kadar. Diş buğdayını evde kendimize kadar yaptım anneanne, babaanne falan akşam yemeği yer gibi yedik. Illk yaşında da yakın akraba ve arkadaşlarımız geldi bir pasta kestik o kadar zaten çocuk bir şey anlamıyor. Armağan falan da hazırlamadım" (A.27, 25 yaş).

Bazı anneler ise tam tersi geleneksel uygulamaların bir kısmını gerçekleştirmemiş, gerçekleştirdiklerini de modernleştirerek günümüze uygun hale getirdiğini belirtmiştir.

“...yaptıklarımı düşününce, ben daha çok annemlerin, yaşllların yapmadıklarını yaptım diyebilirim. Etrafimdakiler de daha çok öyle yapmışı aslinda ben de bir anlamda çağa uygun olsun istedim. Yine annelerimizin yaptığ doğum günüdür, mevlittir onları yaptım ama ortamı süsledim, hediyeler dă̆ıttım öyle olunca geçmişte yapılanlardan ayrılmış oldu" (A.44, 30 yaş).

Bazı katılımcılar ise uygulama konusunda sadece günümüzde ortaya çıkmış pratikleri benimsediklerini vurgulamıştır.

“...zaten anneler, nineler zamanında yapmış ben farklı şeyler yapmak istedim. O yüzden baby shower ile başladım, hastane odamı süslettim, hatta benim zamanımda olsa kesinlikle şu cinsiyet öğrenme partisinden de yapardım. Bunlar da günümüzün gelenekleri sonuçta” (A.31, 42 yaş).

Derinlemesine görüşme esnasında elde edilen verilere göre annelerin kutlama ve armağanlaşma pratiklerini gereksiz bulmalarının çeşitli nedenleri vardır. Bu nedenler annelerin deneyimlerine, sosyo-kültürel çevrelerine, sosyal medyayı kullanım şekillerine ve diğer farklı etkenlere göre değişmektedir. Annelerin bu uygulamaları gereksiz bulma nedenlerinden biri uygulamaların herhangi bir toplumsal zorunluluk içermemesi ve bireysel kararın bir neticesi olarak yorumlanmasıdır. Aşağıdaki örneklerde de bu durum gözlenmektedir.

“...herkesin kendi keyfi, kendi isteği, kendi arzusu bence. Her ne kadar bu konuda bir mahalle baskısı olmaya başlasa da bu baskiyı hayatına yansitmak, yansitmamak bunların hepsi kişiye ait kararlar bence" (A.32, 37 yaş).

“...bence gerekli değil, yapsanız ne olur yapmasanız ne olur? Sonuçta bu kutlamaların asıl aktörü yani bebeğiniz hiçbir şey anlamıyor. İleride birkaç resme bakacak sadece. Kimse de zorlamiyor illa yap, et diye kişiler ama daha çok anneler tamamen kendileri karar veriyorlar bence" (A.36, 25 yaş).

Annelerin bu uygulamaları gereksiz bulma nedenlerinden diğeri ise özellikle bu kutlamalarda verilen armağanların ve harcanan para miktarının görece gereksiz bulunmasıdır.

"Çok gereksiz buluyorum, onların hepsi alınıp çöpe atılyyor. Kendi çocuğumunkileri saklamayı tercih ederim" (A.1, 31 yaş),

"...Bence bunun artık önüne geçilmesi lazım, ben şahsen çok sılkıldım, evimin her yeri böyle saçma sapan şeylerle dolu. Atayım diyorum atamıyorum ama hoşlanmiyorum da. Mesela bu ay iki sünnet vardı bizim sitede biri 3 ayrı her şey verdi. Nazar boncuğu, çocuk fotoğrafi verdi ben ne yapayım onun fotoğrafinı. Kendime yapar miydım? Bu şekilde yapmazdım, çok yakınlarıma hatıra kalsın isterdim ama bunu bir şölene 
dönüşı̈̈rüp abartmazdım” (A.12, 32 yaş).

“...nefret ediyorum bu şeylerden, zaten hiçbir şey yapmadım. Ne kadar gitmeyeceğim desem de ya da gitmesem de sağdan, soldan bir sürü ıvır zıvır geliyor onun kızının, bunun oğlunun dişi çıkmış, doğmuş, yürümüş, bir yaşına girmiş, hami olmuş falan filen artırın artırabildiğiniz kadar. Evim dolabım doldu taştı saçma sapan şeylerle, ay bebek resmi var diyorum atamıyorum da ama hoşnut değilim bence bu saçmalık” (A.28, 35 yaş).

Annelerin bu uygulamaları gereksiz bulma nedenlerinden bir diğeri de katılımcı annelerin bir kısmının geleneksel uygulamaları daha mütevazi bularak yeni modern uygulamaları tercih etmemeleridir.

“... olumlu bakmıyorum bence çok gerekli değiller. Çocuklar açısından ileride olumsuz etkileri olacağını düşünüyorum. Annelerin bu tutumu bana garip geliyor, aile ortaminda gerçekleşen doğum günleri bence çok daha iyi, daha sicak geliyor. Diğer türlü bir yarışa dönüşüyor. Arkadaşlarım arasında bu bir yarış herkes bir üstünü yapıyor, herkes bir üstünü yapıyor ve bunun bir sonu yok" (A.2, 27 yaş)

“...bizlerin anneleri yapmamış böyle şeyler hiç bence pek de güzelmiş. Ben annem, anneannem ne yaşadiysa bir anlamda onu yapıyorum, abartmadan. Çünkü sonu yok, o kadar çok abartıliyor ki bence gereksiz bu yüzden. Eskiden daha mütevaziymiş bu şeyler, insanlar da daha mutluymuş böyle anlamsız, gereksiz yarışlar yokmuş, bence daha doğru" (A.39, 29 yaş).

Araştırmaya katılan annelerin bazıları da söz konusu kutlama ve armağanlaşma pratiklerinin büyük bir ekonomik sektör olduğuna dikkat çekerek söylemlerinde bu kutlamaların ticarileşmesine dikkat çekmişlerdir.

“...Gerekli değil bence. Insanların hevesi de ilgisi de var. Tüm detayları isteyenler var, bu bir sektör oldu, insanları sömürüyorlar. Oda süslemesi mesela 2000 verenler var ama o tülün maliyeti çok daha az. Çok ciddi paralar dönüyor, ciddi bir sektör oldu ve ben insanların artık sömürüldüğünü düşünüyorum” (A.5, 27 yaş),

“...bence gereksiz çünkü çok büyük paralar dönüyor bu işte. Her sokakta bir parti evi var, insanlar sosyal medya hesaplarindan hediyeler, kurabiyeler yapıyorlar, organizasyon firmaları artık dügünlerden çok bu şeylerden para kazanlyor. Üstelik her sene, her yaşta, neredeyse her evrede kutlanacak bir şeyler bulunuyor. Bence bu çllginlık, her şeyin bu kadar ticarileşmesine karşıyım ben” (A.28, 35 yaş).

Bazı görüşmeciler de bu uygulamaları ilk çocuklarında deneyimlemiş ve bir anlamda bu pratiklerden alacakları doyumu sağladıkları için diğer çocuklarında tekrar yapmamışlardır.

“... Gerekli değil kesinlikle ikinci çocuğum olsun kesinlikle yapmam” (A.6, 30 yaş)

“...ben onlardan kusacă̆ım artık, gerçekten böyle hissediyorum. Anne olmadan hiç ilgimi çekmezdi fotoğrafinı görsem o ne diye bakardım. Şimdi, ikinci hamileliğimde yine o aşamaya geldim. Ama ilk çocuğumda müthiş ilgi duydum ama şimdi ikinci çocuğumda çok saçmalık gibi geliyor" (A.12, 32 yaş). 
Yukarıda görüşlerine başvurulan iki annenin en büyük ortak özelliği ikisinin de ikinci çocuklarına hamile olmasıdır. Dolayısıyla kutlama ve armağanlaşma pratiklerini uygulama sıklığının ilk çocuktan ikinci çocuğa doğru azalan bir seyir izlediğini belirtmek mümkündür. Fakat katılımcı annelerin bazıları da iki çocuk sahibi olmalarına ya da ikinci çocuklarına hamile olmalarına rağmen oldukça farklı düşünmektedir.

“... Tabii çok ilgimi çekmiyordu o kadar haberdar değildim hani ama işin içine girince daha çok algın artıyor değişiyor... İlk çocuğumda, yani 7 yll öncesinde daha az böyle şeyler vardı hatta tamamen eskisi gibiydi, bu kadar sektör de malzemede, hediye de yoktu ama şu anda herkes yaptığ için sen de onu yapma gereği duyuyorsun bazen hani misafir geliyor onu da yapmallyım ben diyorsun. Mesela benim iki çocuğum arasında 7 yaş var, dediğim gibi ilk çocuğumda böyle şeyler yoktu ben de ikincisinde yakalamak, hevesimi gidermek istedim iyi ki de yapmışım" (A.19, 34 yass).

“...bence çok keyifli şeyler bunlar ben ilk doğum yaptı̆̆ımda baby showermış, hastane odası süslemeymiş, kü̧̈ük hediyelikler hazırlamakmış yoktu böyle şeyler hiç, 12 yll önce hastaneden sonra direk eve gelir, bir tek 40 mevliti ile ilk yaş yapardık ama şimdi anne de düşünülmüş, misafirler de düşünülmüss, her şey var artık, bir sürü cemiyet olmuş, birçok anı birikiyor ne güzel. İkinci çocuğumda hepsini doya doya yaptım, içimde kalmadı hiçbir şey çocuğuma da birçok anı biriktirdim. Illk çocuğumda olsaydı ona da yapardım ama onun zamanında yoktu. Biraz adaletsizlik mi oldu diye düşünüyorum bazen ama benimle ilgi değil ki, yeni çıtıtı böyle şeyler" (A.48, 41 yaş).

Diğer katılımcıların ifadeleri de göz önüne alındığında annelerin bu kutlama ve armağanlaşma ritüellerinden haberdarlıklarının ve pratikleri gereksiz bulma oranlarının yüksek fakat uygulama ya da benimseme oranlarının hem iki gebelik arasında geçen zamana hem de ilk gebeliklerinde bu pratikleri uygulama ya da uygulamama durumlarına göre değiştiği gözlenmektedir. Annelerin uygulamalara bakışını değiştiren etkenlerden bir diğeri gerçekleştirilen uygulama sayısı olarak karşımıza çıkmaktadır. Bu doğrultuda gerçekleştirdikleri uygulama ve armağan sayısı arttıkça annelerin ilgili ritüellere daha pozitif yaklaştıkları ve görece gerekliliğine inandıkları, bu sayı düştükçe de daha negatif bir bakışa sahip oldukları anlaşılmıştır.

“...ben etrafimda gördüğ̈̈m, çeşitli ortamlardan duyduğum her şeyi yaptım. Ekonomik durumum müsait olduğu için fazlasılla armağan da dă̆ıttım. Fırsatım olduğunca diğer akraba ve arkadaşların yaptı̆g kutlamalara da katıllyorum. Bence çok güzel şeyler bunlar, hatta artık birbirinden uzakta yaşayan yakınları bir araya getirmek, paylaşım gerçekleştirmek için de gerekli” (A.38, 24 yaş).

$\mathrm{Bu}$ uygulamaları gerçekleştirmeye daha ilgili anneler; heves, özen, anı biriktirme gibi kavramları kullanarak bu durumu anlatmaya çalışmışlardır.

“...Ben yapı olarak severim bu tarz şeyleri, o yüzden bana mantıklı gelenleri yaptım. Diğer insanlar neden yapıyor? Bence onların da hoşuna gidiyordur" (A.3,35 yaş).

“...Ben de büyük bir özenme vardl. İlk defa anne oluyorum, çocuğum en klymetlim, ona her şeyi yapmak istedim ama dedim ya sonu yok sonradan kendime geldim. Olması gereken bu değilmiş dedim. Diğer insanlar 
da bence özeniyorlardır" (A.6, 30 yaş).

“...Her aşamada bir kutlama var neredeyse günümüzde, beraberinde ufak tefek armağanlar da veriliyor tabi ama bana fazla geldi hani gerek görmedim çoğuna ama dediğim gibi yadırgamadım da hiç bazıları çok yadırgıyorlar ben öyle değilim. Ben yaptıklarımı tamamen kendim istediğimden ve sonuçta ben yapanlara gidiyorum ben de davet edeyim diye yaptım" (A.25,32 yaş).

Annelerin ifadelerinden hareketle annelik ve çocuk ekseninde gerçekleşen bu kutlama ve armağanlaşma pratiklerini bazı anneler kendi seçimleri doğrultusunda bazıları ise aşağıdaki örneklerde olduğu gibi kendileri istemese de eş, kayınvalide ya da arkadaşların ritüelleri yerine getirmek istedikleri için gerçekleştirmişlerdir.

“...Mesela bizim ailemizde benden ziyade eşim çok meraklı ve o daha çok istedi. O tüm detayları istedi ve yaptı. Sadece bana birakılsa çok fazla yapıp çeşitlendirmeyebilirdim ama yine de yapma ihtiyacı hissederdim" (A.9, 32 yaş).

“...eşim daha çok yaptı aslında, o benden daha meraklı böyle şeylere, sadece bana kalsaydı işte onun doğumuna hatıra olacak küçük bir şey yapardım işte gidip çikolatasıdır kolonyasıdır şudur budur yapmazdım ama eşim oldukça detayl bir şekilde her şeyi ile uğraştı diyebilirim" (A.24, 28 yaş).

Katılımcıların bir kısmı bu uygulamaları gerçekleştirme konusunda üzerlerinde sosyal bir baskı hissettiklerini, sosyal norm ve değerlerin dışına çıkmamak adına söz konusu uygulamaları yerine getirdiklerini anlatmışlardır.

“...Ben istediğim için ve itiraf etmek gerekirse etrafimdaki çoğu arkadaşlarım yaptığı için yaptım. Diğer kişilerin de bu doğrultuda olduğunu düşünsem de özellikle baby shower konusunun tamamen özentilikle alakalı olduğunu düşünüyorum” (A.4, 32 yaş).

“...Çok onaylamadiğım halde gerçekleştirdim hem etrafimın baskısı hem de ben de herkes yapıyor diye düşündüm ve malzeme alıp kendim hazırladım" (A.5, 27 yaş).

“...Bir kere günümüzde yapılmadı̆̆ zaman yadırganıyor. Ama benim yapma nedenim daha çok çocuğum için bir anı biriktirmek, kendi açımdan da moralime iyi gelmesi oldu. E tabii özellikle mevlit konusunda ailelerin de bir yaptırımı oldu. Şart da değil ama gösterişi seven, zengin olduğunu göstermek isteyen insanlar için bu tarz şeyler çok güzel bir firsat. Insanlar âdeta hayatı algılama ve uygulama biçimlerini yansittyorlar" (A.7,28 yaş).

“...Yapmasan olmaz gibi artık, hiçbir şey yapmadı̆̆ın zaman kendini tuhaf hissetmene neden oluyor bu durum. Mesela bizim ailemizde benden ziyade eşim çok meraklı ve o daha çok istedi. O tüm detaylarl istedi ve yaptr. Sadece bana birakılsa çok fazla yapıp çeşitlendirmeyebilirdim ama yine de yapma ihtiyacı hissederdim" (A.9,32 yaş).

Katılımcılar tarafindan gerçekleştirilen kutlama ve armağanlaşma pratiklerine ilişkin ifade ve yaklaşımları artırmak mümkündür. Fakat katılımcıların ortak davranışları söz konusu olduğunda pratiklere geliştirilen tutumlardaki etkileyici unsurların oldukça fazla olduğu ve kişiden kişiye değiştiği belirtilmelidir. Bu doğrultuda Cengiz’e (2009) göre içinde yaşadığımız modern yaşam 
biçimi zaten arzuların, ihtiyaçların, toplumsal ve bireysel seviyelerdeki taleplerin ve bu sistem içindeki tüm kaynakların birbirini etkilediği bir tüketim kültürünce şekillenmektedir. Bu bakıştan hareketle çalışma kapsamında bir tüketim unsuru olarak ele alınan ritüelleri hem katılımcıların hem de katılımcıların gözlemlerinden hareketle diğer annelerin gerçekleştirme nedenleri irdelenmiştir. Anneler çoğunlukla heves, özen, anı biriktirme, kendini iyi hissetme, gösteriş, yarış, rekabet, abartı ve moda gibi nedenlerle kutlama ve armağanlaşma pratikleri içerisinde yer almışlardır.

Annelerin hem kutlama hem de armağanlaşma ritüellerini gerçekleştirmesinde ve şekillenmesinde etkili olan unsurların ilkinin içinde bulunulan sosyal çevre olduğu görülmüş̧ür. Kat1lımcı annelerin anlatılarında sıklıkla vurgulanan bu yaklaşıma göre anneler yakın çevrelerindeki benzer rollere sahip diğer annelerin yani "roldaşlarının" uygulamalarında gerçekleştirdikleri gözlemlerden hareketle kendi uygulamalarının içeriklerini ve sayısını belirlemektedirler.

“...hamileyken çocuğum olunca şunu yapacă̆ım, şunu yapmayacağım diyordum, sonra ilk bebeğime hamile kaldım ve gördüğ̈̈m, katıldı̆̆ım, araşıtırdı̆̆ım şeylerden sonra kendime bir seçim yaptım. Zaten etrafimda hemen hemen herkes bu tarz şeyleri az çok uyguladı̆̆ için kolay oldu kendi yol haritamı çizmek. Bir süre sonra herkes yaptığı için genel kurallar belli oluyor ve yapmayanların ardindan çeşitli dedikodular oluyor. Yani benim çevremde herkes yaptı̆̆ için bu konuda duyarlılar diye düşünüyorum, sonuçta bu bir rutin olduğu için herkesin yapması beklenirken yapmayanlar için de sebepler aranıyor" (A.32, 37 yaş).

Nitekim O'Donohoe ve arkadaşları (2014) da annelerin kendilerini başkaları ile kıyasladıklarına ve bu bağlamda değişen tüketim tercihlerine değinmişlerdir. Onlara göre kullanılan tüketim ürün ve hizmetleri annelerin diğerleri tarafından nasıl görüldüğünün ve yargılandığının yanı sıra annelikleri dâhilindeki birçok uygulamayı da şekillendirir niteliktedir. Benzer bir şekilde armağanlaşma pratiklerinin Türk tarihindeki yerini değerlendiren Sakarya’ya (2006) göre süregelen bu gibi gelenekler sosyal ilişkiler aracılığıyla sosyal itibar ve dayanışma sağlamak, onur kazanmak gibi birçok işlevsel içeriğe sahiptir. Çalışma kapsamında düşünüldügünde her anne farklı bir çevre tarafından kuşatılmıştır. Annelerin kendisini yakın hissettiği gruplar da bu grupların adeta norm haline gelen gelenekleri de kişilerin annelik ve çocuk ekseninde gerçekleştirdikleri ritüellerin çerçevesini çizmektedir. Nitekim Şahin (1992) bu konuda referans grupların öneminden söz eder. Ona göre referans grupları bireylerin özendiği, idealize ettiği ve normlarını benzetmeye, yaşam tarzını yakınlaştırmaya çalıştığı gruplardır. Bu noktada sosyolojinin temel dayanağı olan; toplumun insan davranışlarını kuşattığı, şekillendirdiği savunusu düşünülmelidir. Bu bağlamda annelerin gerçekleştirdikleri ritüellerin türü, içeriği, katılanları ağırlama şekilleri, sundukları armağanlar hem onların içinde bulundukları sosyal çevre tarafından sosyal statülerini belirlemelerine hem de onların da diğer bireyleri bu ritüeller üzerinden değerlendirmelerine neden olmaktadır. Katılımcı ifadelerinden hareketle bu süreçte annelerin daha önce katıldığı benzer pratiklerdeki deneyimleri belirleyici olabilmekte ve diğerleriyle kıyaslanarak gerçekleştirecekleri ritüellerin içeriği değerlendirilmektedir. Dolayısıyla katıldığı kutlamaların sayısı fazla olan anne de bu kutlamaları yapmak isteyebilmekte ya da fazla armağan almış anne kendisi de birden çok armağan hazırlama eğilimine girebilmektedir.

Kutlama ve armağanlaşma pratiklerinin annelerin ekonomik yeterlilik, estetik zevk, olası beklentilerinin değerlendirilmesi bağlamında ipuçları verdiği de söylenebilir. Bir görüşmecinin vurguladığı gibi “...bu uygulamalardaki harcama eşiğinize göre ekonomik durumunuz hakkında bilgi veriyorsunuz aslında” (A.9, 32 yaş). Bu bağlamda annelerin bu ritüelleri gerçekleştirme 
çabasının temel odağı bir sosyal onay arayışı olarak yorumlanabilir. Bu sosyal onay ihtiyacının anne üzerinde iki davranışa sebep olduğu görülmektedir. İlk olarak anne takdir edildiğini düşündüğü herhangi bir kutlama ve armağanlaşma pratiğini kendi koşullarıyla uyumlaştırarak kısmen "taklit" etme yoluna gidebilir. İkinci olarak da anne şimdiye kadar yapılmamış bir şey yaparak görece farklılığını vurgulamak isteyebilir. Bu aşamada gerçekleştirilen "taklit” ya da "benzer uygulamaların" gerekçesi "başkası yapıyor" ya da "herkes yapıyor" gibi cümlelerde ifadesini bulur. Bu noktada Simmel'in (1957) moda akımları taklit eden bireylerin eylem sorumluluğunu başkalarına yükleyerek bu davranışı devam ettirdiklerine ilişkin bakışı akla gelmektedir. Onun bu yaklaşımından hareketle annelerin benzer uygulamaları gerçekleştirme nedenlerini anlamak mümkün görünmektedir.

Chae (2015) ise günümüzde annelik ekseninde gerçekleşen bu uygulamaların nedenini rekabet odağında açıklamaktadır. Ona göre güncel annelik ideolojisinde annelerin deneyimleri karşılaştırılarak, rekabet güçlendirilmekte, hatta ilgili uygulamalar da bu konudaki rekabeti teşvik eden bir konumda bulunmaktadır. Benzer bakış katılımcı ifadelerinde de gözlenmiştir. Bir görüş̧meci konuya ilişkin “...Kadınların arasında rekabet yüzünden böyle, bu kadar fazla, herkes bir yarış içinde âdeta” (A.6, 30 yaş) cümlesini diğer bir görüşmeci de “...bu çok popüler bir yarış gibi. En yakın arkadaşlar bile gizli bir rekabet içinde, herkes en görülmemişi, en iyisini yapma ve bunu çeşitli platformlarda paylaşma niyetinde” (A.30, 31 yaş) cümlesini kullanmıştır.

Annelerin bu ritüelleri gerçekleştirme gerekçelerinden bir diğerinin de "karş1lıklılık" esası olduğunu belirtmek mümkündür. Çalışma kapsamında katılımcı annelerin bazıları kendileri bu gibi kutlama ve armağanlaşma ritüellerine katıldığı için bunları gerçekleştirmek zorunda hissettiklerini belirtmişlerdir. “...ben de şu anda en azından bir şey yapmaya çalışıyorum hem anı olsun hem de bu anlamda başkalarının gözünde az da olsa bir borcum varsa bunu ortadan kaldırayım diye” (A.17, 30 yaş). Benzer bulgu Birekul tarafindan 2014 yılında gerçekleştirilen çalışmada da gözlenmiştir. Nitekim Bauman'a göre de armağanlaşma eş değer mübadelesi ile birlikte toplumsal ilişkinin belirleyicisi ve sürdürücüsü olarak karşılanmaktadır $(1998,102)$. Dolayısıyla “...Sonuçta herkesin yaptıklarına gidiyorsunuz, size küçük de olsa hediyeler veriyorlar. Bir anlamda borçlanıyorsunuz da. Siz de yapıp onları çağırıyorsunuz böylece” (A.4, 32 yaş). Katılımcının ifadesinden de anlaşılacağı üzere armağanlaşma ve kutlamaların hem bir “değiş-tokuş” hem de bir “karşıllklılık” içerdiğinden söz etmek mümkündür. Hatta İnsel (2003) bu bağlamda armağan değişiminde geri vermek kadar verilenleri almanın da önemli olduğundan ve bu sessiz zorunluluğun toplumsal ilişkiyi sürekli kılan bir eylem olduğunu vurgulamaktadır. Zeybek’e (2013) göre de armağanlaşmadaki bu “karşıllklıllk” düşüncesi “sözleşmelerden daha bağlayıcı” (138) olabilmektedir. Bu noktada Godbout'un (2003) armağan ilişkilerinde bir ilke olarak "verdiğin kadar almak" eyleminden söz etmek gerekmektedir. Bu durumu bir görüşmeci “...bu da bir nevi alışveriş aslında, iadei armağan gibi yani. Sonuçta siz gidiyorsanız, siz de çă̆ırmalısınız bu beklentiyi hissediyorsanız ve geniş bir çevreniz varsa da otomatikman yapıyorsunuz zaten" (A.37, 29 yaş) şeklinde ifade etmiştir. Bu bağlamda Demez'in de belirttiği gibi armağanlaşmanın modern toplumda ortaya çıkan biçimini geleneksel anlamda armağan ilişkileri ve karşılıklılık, bağımlılık anlamlarında ele almak gerekmektedir (2011: 88). Birekul 'a göre ise armağanlaşma karakteristik olarak bir karşılıklılık barındırmakta ve armağan verme yükümlülüğü, armağan alma yükümlülüğünü beslemektedir (2014, 37). Mauss’a (2003) göre de bu durum armağanlaşmanın görünüşte gönüllü olsa da aslında zorunlu yükümlülükler taş1dığının bir göstergesi olarak tanımlanmaktadır. Dolayısıyla annelerin de gerçekleştirdikleri armağanlaşma pratikleri üzerinde bu karş111kl11ık etkisini okumak mümkün görünmektedir. 
Çalışma kapsamında irdelenen bir diğer konu da hem katılımcı annelerin hem de onlara göre diğer annelerin bu kutlama ve armağanlaşma pratiklerini gerçekleştirme nedenleridir. Görüşülen annelerin bu uygulamaları gerçekleştirme sürecinde referans aldıkları annelerle kendilerini kıyaslayarak kutlama ve armağanlaşma pratiklerinini yapıp yapmayacaklarına dair karar verdiklerini belirtmişlerdir. Bu bağlamda "...O yaptı ben yapmadım olmasın daha çok show nitelikli. Herkes yapıyor diye yapıyorlar kesinlikle” (A.10, 37 yaş), “...bence insanların çoğu bunu isteyerek yapmıyor. Diğerleri yapıyor diye yapıyorlar"(A.12, 32 yaş) şeklinde annelerden görüşler iletilmiştir. Anneler referans aldıkları annelerle kendilerini kıyaslayarak onlardan geri kalmayarak sürüye katılmaktadır. Bu durum literatürde "Geri kalmama etkisi-Sürüye katılma (Bandwagon etkisinin)” olarak adlandırılmaktadır. Festinger'e (1954) göre de çeşitli medya içerikleri ile diğer annelerin çok yönlü deneyimlerine maruz kalan annelerin davranışları rekabete bağlı olacaktır çünkü karşılaştırma sonucu saptanan tutarsızlıkları azaltmak için diğer annelerle benzer eylemler başlatılmaktadır. Dolayısıyla bu çalışma kapsamında annelerin hem kutlama, armağanlaşma pratikleri hem de annelik rolleri çercevesinde gerçekleştirdikleri tüketim davranışları açısından hâkim kültürü ve sosyal çevrelerinin onayladığı uygulamaları benimsemeyi tercih ettikleri iddia edilebilir. Nitekim Chae'e (2015) göre anneler kendi alanlarındaki hâkim ideoloji ve uygulamalara büyük oranda katılma eğilimindedirler. Bu durumun tüketim bağlamında kutlama ve armağanlaşma pratiklerini benzeştirdiği ve bu pratiklerin tüketim seyirlerini de tek tipleștirdiği belirtilebilir. Güngör (1993) günümüzde özellikle kutlama ve armağanlaşma ritüelleri söz konusu olduğunda annelerin bu pratiklerinin benimseme ve gerçekleştirme nedeninin bir diğer boyutunu âdeta açıklar gibidir. Ona göre tüketim kültüründe birey, üretimde değil tüketimde aktif olarak yer alır, toplumda genel kabul edilen tüketim kalıplarına göre uyma davranışı gösterir ve böylece tek tipleşme ortaya çıkar (Güngör 1993, 135). Tek tipleşen tüketim ise üretim seyrini kolaylaştıracağı için piyasa için tercih unsurudur. Son dönemlerde sayısı gittikçe artan parti evleri, ya da organizasyon firmalarını bu konuya örnek vermek mümkündür.

Annelik çerçevesinde gerçekleşen kutlama ve armağanlaşma ritüellerinde gelir seviyesinin nasıl bir etkiye sahip olduğu da araştırılmıştır. Bu çerçevede anneler görece yüksek gelir seviyesine sahip kişilerin gerçekleştirdiği kutlama ve armağanlaşma pratiklerinden haberdar oldukça -ki bu haberdarlık günümüzde daha çok sosyal medya ve çeşitli kitle iletişim araçları aracılığ1 ile gerçekleşmektedir- gelirleri ne olursa olsun, kendi bütçeleri çerçevesinde bu pratikleri gerçekleştirme ihtiyacı hissedebilmektedirler. Annelerin bu uygulamaları gerçekleştirip gerçekleştirmeme kararında bütçelerinin yetersizliğinin beklendiği kadar etkili olmadığı, sadece tercih edilecek kutlama şekli ve armağanlaşma çeşidi üzerinde daha ekonomik tercihlere yönelme eğilimi olduğu gözlenmiştir. Annelerin kutlama ve armağanlaşma pratiklerine ilişkin bu yaklaşımlarında rekabetçi ve taklitçi özellikleri de görebilmenin mümkün olduğu düşünülebilir. Kıray (2005) anneler arasındaki gösterişçi rekabetin okunabileceği alanlardan birinin periyodik ziyafetler olduğunu belirtmiştir. Annelik çerçevesinde gerçekleşen ve günümüzde "periyodikleşen" bu kutlama ve armağanlaşma pratiklerinin de benzer bir çerçevede olduğunu belirtmek mümkündür.

Görece üst tabakadan alt tabakaya taklitçilik ile aktarılan uygulamalara Simmel (2003) moda kavramından hareketle yaklaşmaktadır. Simmel'in moda kavramını kullanarak açıkladığına göre; üst tabaka moda olanı ilk ortaya çıktığında, yeni ve azken tüketen kesimdir. Onların bu öncülüğünün ardından piyasada alternatifleri üretilerek kolay bulunur hale gelen moda konusu olan ürün ya da hizmet alt tabakalar tarafından da tüketilmeye başlar. Böylece alt tabaka üst tabaka gibi yaşayabildiğini hissederken aynı zamanda kendi ölçeklerinde moda olana da uymuş olur. Nitekim annelerin büyük bir çoğunluğu (43 kişi) annelik ve çocuk ekseninde gerçekleşen bu ritüellerin bu kadar yaygınlaşmasını ve tercih edilmesinin öncelikli sebebini uygulamaların moda haline gelmiş olmasıyla açıklamıştır. Görüşmeciler konuya ilişkin düşüncelerini “...Kesinlikle bu gibi şeyler artık günümüzde moda oldu. Çok uzun bir geçmişi yok. Birden bire tanıştık baby showerlarla falan” (A.1, 31 yaş), “...kesinlikle moda tabii ki, parası olsun olmasın herkesin bunu yapma çabası da moda olduğu için bence. Herkeste bir modaya 
uyma çabası var" (A.32, 37 yaş) şeklinde ifade etmişlerdir. Tıpkı bazı annelerin gerçekleştirdikleri kutlama ve armağanlaşma pratiklerinin gerekliliği sorgulamamaları gibi, moda akımlarını taklit ve takip eden bireyler de Kadıŏglu'na (2014) göre moda unsurunun kendisine yakışıp yakışmadığını, estetik bir görüntü verip vermediğini ya da gerekli olup olmadığının sorumluluğunu modayı yaratan ve yayanlar ile ilişkilendirirler. Bu noktada gelen eleştirilere verilecek cevap da netleşmiş olur. Görüşmeciler "ama herkes yapıyor, ama herkes alıyor, ama herkes giyiyor”. “...moda çünkü herkes birbirininkini takip ediyor. Daha güzelini yapmaya çallşlyor bu bir yarış gibi oldu” (A.6,30 yaş), “...aslında birçok anne, herkes yapıyor diye yapıyor kesinlikle yani kim yapmak ister ki sonuçta hava ya saçılmış bir para” (A.20, 36 yaş) cümleleriyle bu durumu anlatmışlardır.

“...bu tarz şeyleri sevdiğim için hepsini yapmaya çalıştım ama etrafimda da çok faklı düşünceleri, kutlamaları, armağanları yapanlar var. Bir grup aşırl zengin mesela. Acayip bir tantana, acayip bir gösteriş, 'bak ben ne kadar zenginim demek için yaplyorlar sanki. Böyle zengin olanların arasindaki en net şey rekabet. Bir gittiği 3 hediye veriyorsa, diğeri 5 hediye veriyor. Diğer tarafta da zengin olmayanlar ya da bu tarz şeyleri sadece yapmış olmak için yaparak çok para harcamayanlar var. Onlar arasinda da gösteriş yok ama taklit var. Herkes bir diğerinin yaptı̆̆ının aynısın yapıyor. Herkesin yansitmak istediği bir şey var sonuç olarak kimi zenginliğini, kimi algısını, kimi imajını, kimi yaşam tarzını, kimi de estetiğini. Yani herkesin bunların yapmak ya da yapmamak için nedenleri var kendine göre" (A.31, 42 yaş).

“...çok yaygınlaştı bu gibi şeyler günümüzde ama bakınca bu da bir yansıma gibi. Kimisinin söylediğiniz gibi imajı, kimisinin moda algısı, kimisinin gösteriş meraklllı̆̆l, kimisinin de kimliği yansıyor. Normal aslında sonuçta herkes farklı" (A.50, 29 yaş).

Katılımcı anlatılarından hareketle bireylerin çeşitli gerekçelerle benimsedikleri, önemsedikleri ya da sahip olmak istedikleri yaşam tarzlarını sundukları ortamların günümüzde çeşitlendiğini belirtmek mümkündür. Hatta Özdemir’e (2009) göre kişiler bu ritüeller aracılığıyla sahip oldukları yaşam tarzlarını başkalarına sunarak hem yaşamlarını anlamlı kılmakta hem de bireysel tercihlerle kendi değerlerini en üst düzeye çıkarmaktadırlar. Günümüzde annelik ve çocuk ekseninde gerçekleştirilen kutlama ve armağanlaşma ritüelleri de bu bağlamda yaşam tarzlarının sergilendiği pratiklerden biri olarak karşımıza çıkmaktadır. Ayrıca derinlemesine görüşmelerde öncelikle annelere imaj, yaşam tarzı, kimlik gibi günlük hayatlarında kullandıkları kavramlara kutlama ve armağanlaşma pratiklerine yükledikleri anlamlar da sorulmuştur. Görüşmecilerden gelen cevaplardan iki tanesi aşağıda paylaşılmıştır.
“...kişilerin yaşam tarzları hakkında da, imajları hakkında da, maddi durumlar hakkında da ipuçları veriyor bu partiler. Ne kadar şaşalı ise o kadar zenginsin gibi” (A.1, 31 yaş).
“...bir imaj yansittyor günümüzde bence 'bak zengin, bak özenli`falan diyorlar. O kutlamalara ve verdiğiniz armăganlara dönük yaşam tarzı analizleri yapmak da çok mümkün bakalım zevkli misiniz, paranız var $m l$, herkes gibi misiniz yoksa farklı zevkleriniz, yaratıcı armağanlarınız var mı... bunun gibi birçok soru var insanların umursadı̆̆ı" (A.32, 37 yaş).

Katılımcıların benzer görüşlerini çoğaltmak mümkündür. Belli bir noktadan sonra konu dâhilinde fikirlerin benzer olduğu ve birbirini tekrar ettiği gözlenmiştir. Genel olarak anneler tarafindan gerçekleştirilen kutlama ve armağanlaşma ritüellerinin gösterişçi tüketim, moda, 
imaj, kimlik ve yaşam tarzlarıyla ilişkili olduğu iddia edilebilir. Bu bağlamda annelerin bir kıs$\mathrm{m} ı$ herkes ile benzer uygulama ve ritüelleri benimserken bir kısmı da farklılık arama çabasında olmuştur. Dolayısıyla annelerin hem kutlamalara hem de armağanlaşmalara dair beğenileri benzeşmekte ya da farklılaşmaktadır. Bourdieu'ya (2015) göre de günümüzde beğeninin sınıflandırıcı bir içeriği bulunmaktadır ve anneler de özellikle kutlama ve armağanlaşma pratikleri açısından bu "beğeni etkisini" hissetmektedirler. Bu durumda Bauman'a göre bilindikleşen ve kabalaşan uygulamaların yerlerine sabırsızlıkla başka bir şey konacaktır (2005, 228). Dolayısıyla bu ritüellerin değişen, farklılaşan içeriğini Bauman'ın bu yaklaşımdan hareketle çözümlemek mümkündür. $\mathrm{Bu}$ doğrultuda bazı anneler için yaşamlarını anlamlı kılmada uygulamaların gerçekleştirilmesi önemli hale gelebilir. Bireylerin yaşamlarını anlamlı kılma ve anlamlı kıldıklarını kendileri ve kendileri gibi olan diğerlerine aktarmada kullanacakları tüketim metalarını seçerken, ayrıksılığı esas almaları, popüler kültür olarak tanımlanmış alandaki ürünlere başvurulmasını kaçınılmaz hale getirmiştir (Tellan 2009, 77).

Kişilerin kutlama ve armağanlaşma pratikleri ekseninde benimsediği, gerçekleştirdiği bir anlamda bir tüketici olarak satın aldığı ürün ve hizmetler kişiliklerinden, imajlarından, kimliklerinden, yaşam tarzlarından ipuçları taşımaktadır. Örneğin Aydoğan (2005) tarafından gerçekleştirilen çalışmada elde edilen verilerinden biri insanların gereksinim değil, rekabet nedeniyle satın alma davranışı gerçekleştirdikleridir.

\section{Kutlama ve Armağanlaşma Pratiklerinin Yarattığı Olası Baskıya İlişkin Bulgular}

Katılımcılara çalışma kapsamında sorulan bir diğer soru da gerçekleştirdikleri ve gözlemledikleri kutlama ve armağanlaşma pratiklerinin anneler üzerinde bir baskı yaratıp yaratmadığ 1 ve görece yarattığ büyük bir kısmı (42 kişi) bu baskıyı hem hissettiklerini hem de gözlemlediklerini belirtmişlerdir. Açıkalın ve Erdoğan'a göre toplumun tamamı tarafından fark edilir boyutta olan çeşitli yaptırımlar, bu durumu gözlemleyen kişileri psikolojik bir baskı altına alarak tüketime yönlendiren bir içeriğe sahiptir $(2005,2)$.

“...kesinlikle büyük bir baskı var çünkü az da olsa yapmak zorunda bırakıyor ve insanların maddi koşullarına göre zor durumda kallyorlar." (A.3, 35 yaş),

“...hem baskı hem de gereksiz bir stres unsuru insan kendine haksıllı̆g ediyor bu şeylere kapllarak bence, gerek yok gerçekten yok. Ben çocuğumu seviyorum, değer veriyorum ve bunu yapıyorum diyor aslında bu hissedilen baskıdan da doğan bir şey. Çünkü öyle bir ortam var ki; sanki bunları yapanlar daha iyi ve özenliymiş. Yoksa çocuk bundan ne anlasin yoksa" (A.10, 37 yaş).

“...Baskl var hem de çok var bence. Bu toplumsal ve sosyal bir şey bence yapmayayım diyorsanı ya paranı yok, ya özensizsiniz, ya zevksizsiniz, ya bencilsiniz... bu liste böyle uzaylp gidiyor bir sinav gibi oldu sanki artık. Gerçekleştireceğiniz kutlama ve vereceğiniz armağanlar her neyse gizli bir jüri bunu denetliyor ve siz bunun farkında olduğunuz an duyarsız kalamıyorsunuz hep en iyisini yapmaya çalışıyorsunuz" (A.48, 41 yaş).

Katılımcı ifadelerinden de anlaşılabileceği gibi kutlama ve armağanlaşma ritüellerinin baskı yaratan içerimleri çok çeşitlidir. Bu bağlamda Clarke'a (2007a) göre çocukların doğum günü partisi kültüründe anneler birçok içeriği ve yetkinliklerini gerçekleştirdikleri kutlamalar arac1lığıyla diğerleri ile paylaşmaktadır. Bunlar arasında çocuklar, armağanlar, rekabetçi ilişkiler 
ve bu kavramlara dönük yaratıcı uygulamalar da bulunmaktadır. Bu baskıyı hisseden anneler, gerçekleştirdikleri kutlama ve armağanlaşma pratikleri aracılığıyla anneliklerinin, özenli hallerinin, estetik zevklerinin, maddi durumlarının adeta notlandırıldığını düşünmektedirler. Nitekim Veblen'e (2005) göre de çocuklar ailelerin sınıf durumlarının dışa vuran ifadeleri olarak düşünülmektedir. Ona göre bir çocuğun gösterdiği saygınlık açısından çocuk dünyaya geldikten sonra gözle görülür tüketim ve dolayısıyla artan masraf çok önemlidir. Bu bağlamda çocuk ekseninde gerçekleşen kutlama ve armağanlaşma pratiklerini aynı zamanda ailenin sınıfsal konumunu dişa vuran bir gösterge olarak kabul etmek mümkün görünmektedir.

Çalışma kapsamında bazı görüşmeciler böyle bir baskı olduğunu düşünmediği ya da bu baskıyı gözlemleseler de kendi hayatlarına yansıtmadıklarını belirtmişlerdir.

“...bence bu gibi şeylerin bir baskı olması mantıksı, böyle bir bask olduğunu da düşünmüyorum açıkçası, koca koca insanların isteyen yapsin istemeyen yapmasın kimse kimseyi zorlamıyor" (A.50, 29 yaş).

Katılımcı annelerin bazıları böyle bir baskı gözlemlemekte ama bu baskının kendi hayatlarını etkilemediğini vurgulamaktadır.

“...ben bir baskı hissetmedim kendi adıma ama etrafimda bunu yaşayanların olduğunu düşünüyorum. Ben mesela yapmadım, en yakın akrabalarım da eleştirdi ama ben umursamadım, 10 tane de çocuk doğursam yine bildiğimi yapmaya devam ederim. Ama başkaları etkileniyordur mutlaka" (A.21, 38 yaş),

“...yapmak zorunda değil kimse ben öyle düşünüyorum ama kendini baskl altında hissedenler de vardır. Aa işte yapmayacak mısın işte atıyorum diş buğday yapmayacak misin yapman lazım falan filan gibi illa ki bir baskı oluşturuyordur. Ama ben bu baskıyı hissetsem de etkilenmedim diyebilirim" (A.15, 34 yaş).

$\mathrm{Bu}$ düşünceye sahip annelerin demografik özellikleri irdelendiğinde annelerin en az lisans mezunu ve aktif çalışma hayatına devam eden kişiler olduğu belirtilmelidir. $\mathrm{Bu}$ veriden hareketle demografik verilere göre görece yüksek düzeydeki annelerin ilgili uygulamaları baskı unsuru olarak değerlendirmeme eğiliminde olduğunu belirtmek mümkündür.

\section{Sonuç ve Değerlendirme}

İhtiyaca konu olan ürünlerin taşıdığ 1 anlamlar, statü ve prestij belirlemedeki etkileri, toplumsal yaşamda verdikleri örtük mesajlar tüketimi kültürel temellere oturtmakla beraber tüketim ürünlerini adeta soyut nesnelere dönüştürmüştür. Benzer bir şekilde Bocock da tüketimin sadece ekonomik düşünce ve yararcıllk temelindeki ihtiyaçlara değil, gittikçe artan bir şekilde gösterge, sembol ve işaretlerinin de içinde olduğu arzulara dayanan sosyo-kültürel bir olgu olmaya başladığını vurgulamaktadır $(2009,13)$. Günümüzde anneliğin sosyo-kültürel içerikleri arasında kutlama ve armağanlaşma pratiklerini görmek mümkündür. Clarke’a (2014) göre bu uygulamaların etrafında yapılandırılan çeşitli söylemler çağdaş ebeveynliğin çelişkili doğasına benzersiz bir bakış açısı sunmaktadır. Onun bu değerlendirmesinden hareketle günümüz koşullarında anneliğin içerimlerini daha iyi tanımlayabilmek için bu çalışmada kutlama ve armağanlaşma pratiklerine odaklanılmıştır. Günümüzde ticaretle de iç içe geçmiş, detaylandırılmış, çeşitli anlamlar yüklenmiş bu ritüellerin hem annelik hem de tüketim açısından farklı bir fenomen haline geldiği ifade edilmelidir. Bu eksende oluşmaya başlayan tüketim kültürü ürünlerinin de (kutlamalar, armağanlar, hediyeler, kıyafetler vs.) nesilden nesile anneliğin içerdiği belirli anlam ve sosyal dayanışmaların yeniden üretilmesinde büyük bir öneme sahip olduğu 
vurgulanabilir.

Elde edilen bulgulara göre annelik deneyimine sahip kadınların bazıları, kutlama ve armağanlaşma pratiklerini eleştirip para tuzağı olarak "kapitalist odaklarca üretilen unsurlar" şeklinde tanımlamalarına karşın yine de en az bir kutlamayı gerçekleştirmişlerdir. Bu noktada annelerin kutlama ve armağanlaşma pratiklerine bakışları derinleştirilerek annelere bu uygulamaları gerçekleştirmeyi gerekli görüp görmedikleri, hem kendilerinin hem de diğer annelerin bu uygulamaları neden gerçekleştirdiklerini irdelemeye yönelik sorular yöneltilmiştir. Annelerin büyük bir kısmı bu uygulamaları gereksiz gördüklerini belirtirken bazıları bu uygulamaları çağın ve güncel koşulların gerekliliği olarak anlamlandırmıştır. Böylece hem bu uygulamaları gereksiz görüp hem de en az bir uygulama gerçekleştiren kadınlar kendileriyle çelişmişlerdir. $\mathrm{Bu}$ durumun nedenleri üzerine düşünüldüğünde öncelikle Veblen'in (2005) kişilerin genel kültürel değer ve kurallara uyma eğiliminde olduğuna dair düşüncelerine değinmek yerinde olacaktır. Ona göre bireyler içinde yaşadığı grupların genel kültür kurallarına, sergiledikleri tutum ve tavırlara uygun davranışı gösterirler. Bu bağlamda annelerin tamamının bir armağanlaşma değil de kutlama pratiği gerçekleştirmiş olduğu bulgusunu yinelemek gerekmektedir. Çünkü bilindiği gibi annelik ve çocuk eksenindeki kutlama pratikleri geçmişten günümüze devam eden bir ritüelken kutlamalar eşliğinde sunulan, ikramlıklar dışındaki armağanlar oldukça yeni bir uygulamadır. Bu pratiklerin gittikçe yaygınlaşarak çeşitlenmesi bu uygulamaların aşama aşama "genel kültür kuralları" haline geldiğini düşünmemize neden olabilir. Aynı bakış açısı annelerin bu ritüelleri neden yaptıklarının ve diğer kişilerin bu pratikleri gerçekleştirme nedenlerini sorgulama aşamalarının da açıklayıcısı olabilecek niteliktedir. Annelerin bu ritüelleri uygulama esnasında gözettikleri bir diğer unsuru da bu ritüellere atfettikleri anlamlardan hareketle açıklamak mümkündür. Sakarya (2006) süregelen geleneklerin sosyal ilişkiler arac1lığıyla sosyal itibar ve dayanışma sağlamak, onur kazanmak gibi birçok işlevsel içeriğe sahip olduğuna değinmektedir. Katılımcıların anlatılarından elde edilen bulgulara göre de anneler bu gibi güncel ve bazılarına göre gelenekselleşmiş uygulamaların gelenekleri sürdürmek, kutlamaya katılanlara değer vermek, güncel yaklaşımları takip etmek gibi işlevlerine vurgu yaparak bu uygulamaları gerçekleştirme nedenlerini açıklamışlardır.

Annelerin bu uygulamaları gerçekleştirme nedenleri ile onlara göre diğer annelerin bu ritüelleri kabul edip uygulama nedenleri paralellik göstermektedir. Katılımcılar bu uygulamaları gerçekleştirme nedenlerini heves, özenti, gösteriş, karş1lıklılık, anı biriktirme, moda, aile bireyleriyle buluşmaya olanak sağlama, imaj, yaşam tarzı, kimlik, sosyal bilinç gibi kavramlarla açıklamışlardır. Katılımcılar heves, özen, kendisini iyi hissetme gibi çoğunlukla içsel etkenler sonucunda bu gibi ritüelleri gerçekleştirdiklerini vurguladıkları gibi gösteriş, karşılıklılık, değiş -tokuş, moda akımlar, rekabet gibi daha çok dışsal sayılabilecek etkenleri de bu gibi uygulamaları gerçekleştirme nedenleri arasında göstermişlerdir. 


\section{KAYNAKÇA}

Açıkalın S. \& Erdoğan L. (2005). "Veblen'ci Gösteriş Amaçlı Tüketim”. SÜ İ̈BF Sosyal ve Ekonomik Araştırmalar Dergisi 4/7 (2005) 1-18.

Akay A. (2016). Armağan. Ankara 2016.

Aries P. (1996). Centuries of Childhood. Virginia 1996.

Ateş C. (2013). Armağanın Tarihsel Dönüşümü ve Modernizmle Birlikte Tüketim Ürünü Olarak Televizyon'da Sunumu: Sevgililer Günü Örneği. Yüksek Lisans Tezi. Selçuk Üniversitesi, Sosyal Bilimler Enstitüsü. Konya 2013.

Aydoğan F. (2005). Medya ve Tüketim Kültürü Üzerine Eleştirel Bir Analiz. İstanbul 2005.

Balta E. P. (2005). “Bitmeyen Çocukluk, Erken Yetişkinlik ve Yeni Kapitalizm”. Birikim 192 (2005) 20-28.

Bataille G. (1999). Lanetli Pay. Çev. M. M. Yakupoğlu. Ankara 1999.

Bauman Z. (1998). Sosyolojik Düşünmek. Çev. A. Yılmaz. İstanbul 1998.

Bauman Z. (2005). Bireyselleşmiş Toplum. Çev Y. Alogan. İstanbul 2005.

Beck U. \& Gernsheim B. E. (2012). Aşkın Normal Kaosu. Ankara 2012.

Belk R. W. (1977). Gift Giving Behavioir. Chicago 1977.

Besser A., Neria Y. \& Haynes M. (2009). "Adult Attachment, Perceived Stress, and PTSD Among Civilians Exposed to Ongoing Terrorist Attacks in Southern Israel”. Source: <https://www.sciencedirect.com/ science/article/pii/S0191886909003092?via\%3Dihub>.

Birekul M. (2014). Armağan Kültürüu. İstanbul 2014.

Bocock R. (2009). Tüketim. Çev. İ. Kutluk. Ankara 2009.

Bourdieu P. (2015). Ayrım: Beğeni Yargısının Toplumsal Eleştirisi. Ankara 2015.

Burrell G. \& Morgan G. (1979). Sociological Paradigms and Organisational Analysis. New York 1979.

Byström C. "The Ritual Construction of Fetal Personhood a Voyage Through the Gendering of the Unborn in Peruvian Baby Showers”. Source: <https://pdfs.semanticscholar.org/c22c/667ba9d93cb34 c6c54ab 3d41e833e3f2bdd9.pdf>.

Cengiz S. A. (2009). Duygulanım Sarkacının Haz ile Aleksitimi Arasıdaki Salınım: Reklamlarda Kamusal Yüz, Medya, Tüketim Kültürü ve Yaşam Tarzları. Ankara 2009.

Chae J. (2015). “'Am I a Better Mother Than You?’ Media and 21 ${ }^{\text {st }}$ Century Motherhood in the Context of the Social Comparison Theory”. Communication Research 42/4 (2015) 503-525.

Clarke A. (2007a). "Making Sameness: Mothering, Commerce and the Culture of Children's Birthday Parties”. Eds. E. Casey \& L. Martens, Gender and Consumption: Domestic Culture and the Commercialisation of Everday Life (2007) 79-96. Farnham

Clarke A. J. (2007b). "Consuming Children and Making Mothers: Birthday Parties, Gifts and the Pursuit of Sameness”. Source: <http://www.scielo.br/scielo.php?script=sci_arttext\&pid=S0104-71832007000200011>.

Clarke A. J. (2014). Designing Mothers and Market: Social Class and Maternal Culture, Motherhoods, Markets and Consumption, The Making of Mothers in Contemporary Western Cultures. London 2014.

Creswell J. W. (2016). Nitel Araştırma Yöntemleri: Beş Yaklaşıma Göre Nitel Araştırma ve Araştırma Deseni. Ankara $2016^{3}$.

Çeliktaban D. (n.d.). “Çocuk Doğumgünün Sektörü”. Kaynak: <http://www.haberturk.com/yazarlar/ damla-celiktaban/990614-cocuk-dogum-gunu-sektoru>.

Davies A., Dobscha S., Geiger S. \& Prothero A. (2010). "Buying Into Motherhood? Problematic Consumption and Ambivalence in Transitional Phases". Consumption, Markets and Culture 13/4 (2010) 373-397.

Demez G. (2011). “Armağanın Değişen Sosyo-Kültürel Anlamları: Tüketim Toplumu Bağlamında Bir Hediyeleşme Örneği Olarak Çiçek Gönderme”. MJH I/2 (2011) 87-103.

Derrida J. (2005). The Politics of Friendship. New York 2005.

Duncan S. \& Edwards R. L. (1999). Mothers, Paid Work and Gendered Moral Rationalities. Basingstoke 1999. 
Festinger L. (1954). “A Theory of Social Comparison Processes”. Human Relations 7 (1954) 117-140.

Furedi F. (2013). Paranoyak Anne Babalık: Uzmanları Dikkate Almamak Çocuğunu İçin En Iyisi Olabilir. İstanbul 2013.

Giddens A. (2000). Sosyoloji. Ankara 2000.

Godbout J. T. (2003). Armağan Dünyast. İstanbul 2003.

Gönüllü A. R. (2002). “Türkler’de Diş Çıkarma Töreni”. Türk Tarih Dünyası Dergisi 187 (2002) 23-25.

Gram M. \& Pedersen H. D. (2014). "Negotiations of Motherhood- Between Ideals and Practice, Motherhoods, Markets and Consumption”. Eds. S. O’Donohoe, M. Hogg, P. Maclaran, L. Martens \& L. Stevens, The Making of Mother, Motherhoods, Markets and Consumption: The Making of Mothers in Contemporary Western Cultures (2014) 99-114. London.

Gündüz Ş. (2017). "Kariyer Basamaklarında Kadının Düşmanı Olarak Kendisi: Süper Anne Sendromu, Görünme Kadın Sendromu ve Külkedisi Sendromu”. Karadeniz 35 (2017) 78-88.

Güngör N. (1993). Arabesk, Sosyokültürel Açıdan Arabesk Müzik. Ankara 1993².

Hammersley M. \& Atkinson P. (2007). Ethnography: Principles in Practice. London $2007^{3}$.

Homans G. C. (1961). Social Behavior: Its Elementary Forms. New York 1961.

Hurdley R. (2007). “Objecting Relations: the Problem of the Gift”. The Sociological Review 55/1 (2007) 124-143.

Hürmeriç P. \& Baban E. (n.d.). “Simmel, Veblen ve Sombart'ın Penceresinden Hedonik Tüketim: Ütopyada Egotium ve Otium”. Kaynak: <http://globalmediajournaltr.yeditepe.edu.tr/bahar2012sayisi.html>.

Hyde L. (2008). Armă̆an. İstanbul 2008.

İnsel A. (2003). Armă̆an Sorunsalının Açtı̆̆ı Ufuk. Jacques T. Godbout. Armağan Dünyası. İstanbul 2003.

Kadıoğlu Z. K. (2014). Tüketim İletişimi: Süreçler, Algllar ve Tüketici. İstanbul 2014.

Kıray M. (2005). Tüketim Normları Üzerine Karşılaştırmalı Bir Araştırma. Ankara 2005.

Laney A. P. (2014). "Legal and Policy Issues Impacting Pay Equity”. New Jersey Lawyer. Source: <http://www.naaahr-gny.org/wp-content/uploads/2011/03/Equal-Pay-ArticleAndree-Laney.pdf>.

Leblebici D. N. (2008). “Örgüt Kuramının Temelleri”. C.Ü. İktisadi ve İdari Bilimler Dergisi 9/1 (2008) 111-129.

Maier C. (2013). No Kid: Çocuk Yapmamak Iç̧in 40 Neden. İstanbul 2013.

Mauss M. (2002). The Gift: The Form and Reason for Exchange in Archaic Societies. London 2002.

Mauss M. (2005). Sosyoloji ve Antropoloji. Ankara 2005.

McKenna S., Richardson J. \& Manroop L. (2011). “Alternative Paradigms and the Study and Practice of Performance Management and Evaluation”. Human Resource Management Review 21 (2011) 148-157.

Miller T. (2010). Annelik Duygusu: Mitler ve Deneyimler. İstanbul 2010.

Molu B. (2011). 0-12 aylık Bebeği Olan Annelerin Çocuk Bakımında Başvurdukları Geleneksel Uygulamalar. Yüksek Lisans Tezi. Afyon Kocatepe Üniversitesi, Sağlık Bilimleri Enstitüsü. Afyon 2011.

O’Donohoe S., Hogg M., Maclaran P., Martens L. \& Stevens L. (eds.) (2014). The Making of Mother, Motherhoods, Markets and Consumption, the Making of Mothers in Contemporary Western Cultures. London 2014.

Offer A. (2003). "Between the Gift and the Market: The Economy of Regard”. Economic History Review 3 (2003) 450-476.

Otnes C., Nelson M. \& McGrath M. A. (1995). “The Children’s Birthday Party: A Study of Mothers as Socialization Agents”. Advances in Consumer Research 22 (1995) 622-627.

Özdemir N. (2008). “Türk Hediyeleşme Geleneği ve Medya”. Uluslararası Sosyal Araştırmalar Dergisi $1 / 4$ (2008) 467-480.

Rubin H. J. \& Rubin I. S. (1995). Qualitative Interviewing: The Art of Hearing Data. Thousand Oaks 1995.

Saad G. (2011). Tüketim İçgüdüsü: Neden Ferrari, Fast-Food ve Porno Seviyoruz?. İstanbul 2011.

Sakarya C. I. (2006). Türk Kültüründe Hediyeleşme Geleneği ve Hediyeler. Yüksek Lisans Tezi. Hacettepe Üniversitesi, Sosyal Bilimler Enstitüsü. Ankara 2006.

Sarıtaş S. (2011). “The Importance of Wheat in Teething Celebration in Turkish Culture”. International 
Journal of Sociology and Anthropology 3/4 (2011) 120-126.

Server M. (2014). “Kadınlık, annelik, gönüllü çocuksuzluk: Elisabeth Badinter'den Kadınlık mı Annelik mi? Tina Miller’dan Annelik Duygusu: Mitler ve Deneyimler ve Corinne Maier'den No Kid Üzerinden Bir Karşılaştırmalı Okuma Çalışmasıı”. Fe Dergi 7/2 (2014) 72-86.

Simmel G. (1957). “Fashion”. American Journal of Sociology 62 (1957) 541-558.

Simmel G. (2003). Modern Kültürde Çatı̧ma. İstanbul 2003.

Simmel G. (2009). Bireysellik ve Kültür. İstanbul 2009.

Strauss A. \& Corbin J. M. (1998). Basics of Qualitative Research: Techniques and Procedures for Developing Grounded Theory. Thousand Oaks $1998^{2}$.

Şahin O. (1992). Sosyo Ekonomik Yönleriyle Tüketim Fonksiyonu. Yayımlanmamış Yüksek Lisans Tezi. İstanbul Üniversitesi, Sosyal Bilimler Enstitüsü. İstanbul 1992.

Tellan D. (2009). "Bir Tüketim Eylemi Olarak Popüler Kültür”. Ed. E. Karakoç, Medya ve Popüler Kültür (2009) 59-86. Konya.

Thomsen T. U. \& Sørensen E. B. (2006). "The First Four-Wheeled Status Symbol: Pram Consumption as a Vehicle for the Construction of Motherhood İdentity”. Journal of Marketing Management 22/9-10 (2006) 907-927.

Tunç A. (2002). Bir Maniniz Yoksa Annemler Size Gelecek / 70’li Yıllarda Hayatımız. İstanbul 2002.

Veblen T. (2005). Aylak Sinifin Teorisi. İstanbul 2005.

Yıldırım A. \& Şimşek H. (2008). Sosyal Bilimlerde Nitel Araştırma Yöntemleri. Ankara 2008.

Zengingönül O. (2012). Küresel Put: Tüketim Ekonomisi, Yeni Sapkınlı: Sosyal Bilinç. Ankara 2012.

Zeybek S. O. (2013). “'Bu Bebeğin Annesi Nerede?’: Cinsiyet, Babalık ve Armağan İlişkileri”. Toplum ve Bilim 126 (2013) 120-143. 